\title{
Maps of lands vulnerable to sea level rise: modeled elevations along the US Atlantic and Gulf coasts
}

\author{
James G. Titus*, Charlie Richman \\ Office of Atmospheric Programs, US EPA, Washington, DC 20460, USA
}

\begin{abstract}
Understanding the broad-scale ramifications of accelerated sea level rise requires maps of the land that could be inundated or eroded. Producing such maps requires a combination of elevation information and models of shoreline erosion, wetland accretion, and other coastal processes. Assessments of coastal areas in the United States that combine all of these factors have focused on relatively small areas, usually 25 to $30 \mathrm{~km}$ wide. In many cases, the results are as sensitive to uncertainty regarding geological processes as to the rate of sea level rise. This paper presents maps illustrating the elevations of lands close to sea level. Although elevation contours do not necessarily coincide with future shorelines, the former is more transparent and less dependent on subjective modeling. Several methods are available for inferring elevations given limited data. This paper uses the US Geological Survey (USGS) $1^{\circ}$ digital elevation series and National Oceanic and Atmospheric Administration (NOAA) shoreline data to illustrate the land below the 1.5 and $3.5 \mathrm{~m}$ contours for areas the size of entire US states or larger. The maps imply that approximately $58000 \mathrm{~km}^{2}$ of land along the Atlantic and Gulf coasts lie below the $1.5 \mathrm{~m}$ contour. Louisiana, Florida, Texas, and North Carolina account for more than $80 \%$ of the low land. Outside of those 4 states, the largest vulnerable populated region is the land along the Eastern Shore of Chesapeake Bay stretching from Dorchester County, Maryland, to Accomac County, Virginia.
\end{abstract}

KEY WORDS: Sea level rise · Maps · Coastal erosion · Digital elevation model $\cdot$ Climate change · Global warming · Greenhouse effect

Resale or republication not permitted without written consent of the publisher

\section{INTRODUCTION}

Throughout the 20th century, the level of the oceans rose relative to the Atlantic and Gulf coasts of the United States (see, e.g., Lyle et al. 1986, Permanent Service for Mean Sea Level 1999). Because the concentrations of carbon dioxide (Keeling et al. 1989, 1995), concentrations of other greenhouse gases, and global temperatures have also been rising (e.g., Intergovernmental Panel on Climate Changel [IPCC]

\footnotetext{
*Project Manager for Sea Level Rise. E-mail: titus.jim@epa.gov The author is also member of the legal bars of Maryland and the District of Columbia and a contributor to several assessments by the Intergovernmental Panel on Climate Change. The opinions in this article do not necessarily reflect the official views of the Environmental Protection Agency. The US Government reserves the right to duplicate this article for official use
}

1996a), a scientific consensus gradually emerged that there is a serious risk that the rate of sea level rise will accelerate sometime during the 21 st Century. ${ }^{1}$ Recent assessments indicated that a $1 \mathrm{~m}$ rise in sea level is likely to occur over a period of $200 \mathrm{yr}$, but could occur as soon as the year $2100 .^{2}$

The prospect of a large rise in sea level has confronted policy makers with two fundamental questions: (1) Given the risk, what if anything should we do now

\footnotetext{
${ }^{1}$ Mercer (1978), Environmental Protection Agency (EPA) (1983, 1995), National Academy of Sciences (1983, 1985), and IPCC $(1990,1996 a)$

${ }^{2}$ See EPA (1995) at 145 (estimating that a $1 \mathrm{~m}$ rise has a $1 \%$ chance of occurring by the year 2100 and a $50 \%$ chance of occurring by the year 2200, along those coasts where sea level is currently rising $18 \mathrm{~cm}$ per year, which is the global average rate). See also IPCC (1996a) at 6 (reporting that greenhouse gases alone could raise sea level as much as $85 \mathrm{~cm}$ during the period 1990-2100)
} 
to prepare for the inundation, erosion, flooding, and salinity increases from such a rise? (2) Are the likely impacts of a large rise in sea level great enough for those who care about our coastal areas to support measures to reduce emissions of greenhouse gases?

Maps and tabulations of the areas that the maps depict have been key to assessing both questions. The US Government's first integrated assessment of sea level rise included maps showing direct inundation (Kana et al. 1984), shoreline erosion (Kana et al. 1984, Leatherman 1984), and changes in flood boundaries (Kana et al. 1984) for Charleston, South Carolina, and Galveston, Texas. The EPA (1989) Report to Congress estimated the nationwide loss of land and cost of holding back the sea using a map-based model (Park et al. 1989) that included direct inundation, wave erosion from sea level rise, and the vertical accretion of wetlands. The Federal Emergency Management Agency's Federal Insurance Administration (1991) estimated the likely increase in the $100 \mathrm{yr}$ coastal flood plain from a 30 or $90 \mathrm{~cm}$ rise in sea level.

During the 1990s, researchers in many other nations began to assess the land that could be threatened by a rising sea. In Japan, where tsunamis are a concern, assessments have tended to focus on flooding (see, e.g., Mimura et al. 1992). Researchers in Australia (Kay et al. 1992), Senegal (Niang et al. 1992) and Uruguay (Volonte \& Nichols 1995), by contrast, have focused on coastal erosion, employing the Bruun (1962) Rule. Nevertheless, the studies that projected the greatest loss of land have generally been those assessments that used information on elevations to estimate the area of land that is within (for example) $1 \mathrm{~m}$ of the high water mark, such as studies of China $\left(35000 \mathrm{~km}^{2}\right.$; Han et al. 1995), United States $\left(35700 \mathrm{~km}^{2}\right.$; Titus et al. 1991), Bangladesh $\left(25000 \mathrm{~km}^{2}\right.$; Huq et al. 1995), Nigeria $\left(18600 \mathrm{~km}^{2}\right.$; Awosika et al. 1992), and Germany (13900 km²; IPCC 1998 [citing studies published in German by Sterr \& Simmering 1996 and Ebenhoe et al. 1997]). IPCC (1996b) published a table ${ }^{3}$ showing that researchers in 23 nations had estimated the area of land that could be threatened by rising sea level. Like the assessments in the United States, the vast majority of those assessments failed to publish maps illustrating the land at risk.

Efforts to project flooding and shoreline change require (1) data on land and water surface elevations, and (2) a model of coastal processes. Some questions can be answered with elevation data and no model. For example, if mean high water has an elevation of $1 \mathrm{~m}$, then in areas with little wave erosion, the $1.5 \mathrm{~m}$ contour is a good estimate of the area that would be

\footnotetext{
${ }^{3}$ See IPCC (1996b, p. 308, Table 9-3)
}

inundated at high tide if the sea rises $50 \mathrm{~cm}$, assuming that no measures to hold back the sea are implemented. At the other extreme, along the typical oceancoast barrier island, a good model of erosion is impor-

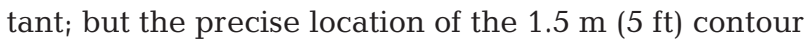
may be almost completely irrelevant. ${ }^{4}$ In areas where wetlands dominate, one needs both good elevation information and a model of how wetlands erode and accrete, as well as a scenario regarding future shore protection efforts.

This paper presents maps depicting the elevations of US lands close to sea level along the Atlantic Ocean and the Gulf of Mexico, for use in the regional assessments comprising the US National Assessment ${ }^{5}$ and similar assessments of the impacts of long-term accelerated sea level rise. Because the regional assessments are an ongoing process, with intermediate milestones, we present rough first-order maps, which we have prepared for the entirety of the 2 coasts, as well as a more accurate procedure that we plan to apply over the next few years. The next section provides background on the available data on coastal elevations. Section 3 describes (1) previous efforts to map the impacts of sea level rise, and (2) how the better data now available in digital form could yield better maps. Section 4 presents state-specific and multistate maps that depict the land below the 1.5 and $3.5 \mathrm{~m}$ contours. Section 5 discusses both what we learned from these maps and how the maps can be used to increase public awareness of the possible impacts of rising sea level.

We warn the reader at the outset that this article presents elevations, not future shorelines. This limitation

\footnotetext{
${ }^{4}$ E.g. Bruun (1962) estimated that shoreline erosion due to a rise in sea level is equal to the rise in sea level divided by the average slope of the entire beach profile from the crest of the dune to a water depth beyond which waves do not transport sediment. Although the height of the dune (or cliff) affects erosion from sea level rise in this model, the precise shape of the profile does not, which implies that the location of an intermediate contour such as the $1.5 \mathrm{~m}$ contour does not have a major effect on erosion

${ }^{5}$ The National Assessment is coordinated by the United States Global Change Research Program. This ongoing assessment was required by an Act of Congress, known as the 'Global Change Research Act of 1990' (P.L. 101-606), codified at 15 U.S.C. $\S \S 2921-2953$. The Act states that the federal government 'shall prepare and submit to the President and the Congress an assessment which (1) integrates, evaluates, and interprets the findings of the Program and discusses the scientific uncertainties associated with such findings; (2) analyzes the effects of global change on the natural environment, agriculture, energy production and use, land and water resources, transportation, human health and welfare, human social systems, and biological diversity; and (3) analyzes current trends in global change, both human-inducted and natural, and projects major trends for the subsequent 25 to 100 years.' 15 U.S.C. $\$ 2936$
} 
may disappoint those who would like to be able to say which areas will be under water if sea level rises a meter or so, but our limited resources left us with no choice but to limit the scope of these maps. Nevertheless, we hope that this approach may find favor among those who would not be inclined to automatically trust our best guess of future erosion, wetland accretion, and land use decisions regarding the areas that will be protected by coastal engineering measures. Elevation does not by itself tell us what will be under water if sea level rises a meter or so; but it is the most important single fact for anyone trying to answer that question.

We hope that this paper encourages researchers in other nations to prepare and distribute maps showing the land vulnerable to a rise in sea level. Because the type and quality of data, as well as what people mean by vulnerability, vary from nation to nation, our approach is not universally applicable. Human nature, however, is more similar from nation to nation than data availability, and part of human nature is that some people find maps more useful than the tables, prose, and time-series charts that have comprised most assessments of the impacts of sea level rise.

\section{BACKGROUND}

\subsection{Data limitations}

The available elevation data confront anyone attempting to estimate the amount of land within a meter of sea level with two unpleasant realities: the available data are inaccurate, and they do not tell us how far the land is above sea level anyway. These problems are commonly known as 'poor vertical resolution' and 'inconsistent benchmarks'.

\subsubsection{Vertical resolution}

The collection of 7.5 min quadrangles of the United States Geological Survey (USGS) is the best nationwide data source. The contour interval is generally $5 \mathrm{ft}$ $(1.5 \mathrm{~m})$ in the southeastern United States, more than twice the rise in sea level expected in the next century. (Because most topographic maps in the United States measure elevation in feet, we include this measure when discussing US topographic maps.) Elsewhere, the information is even worse: $3 \mathrm{~m}(10 \mathrm{ft})$ contours for

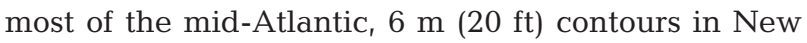
England, and sometimes even $12 \mathrm{~m}$ (40 ft) contours along the Pacific Coast. The vertical resolution is still worse with some of the digital products, as we discuss in Section 4.
Table 1. Vertical resolution of topographic maps in various nations

\begin{tabular}{|c|c|c|c|}
\hline Nation/region & $\begin{array}{l}\text { Typical } \\
\text { units }\end{array}$ & $\begin{array}{l}\text { Typical con- } \\
\text { tour interval }\end{array}$ & $\begin{array}{l}\text { Contour in areas } \\
\text { with good coverage }\end{array}$ \\
\hline Antigua $^{a}$ & $\mathrm{~m}$ & $3-6$ & - \\
\hline Argentina $^{\mathrm{b}}$ & & None & - \\
\hline Bangladesh $^{\mathrm{c}}$ & $\mathrm{ft}$ & 50 & 1 \\
\hline China $^{\mathrm{d}}$ & $\mathrm{m}$ & 1 & - \\
\hline Egypt $^{\mathrm{e}}$ & $\mathrm{m}$ & 1 & - \\
\hline Marshall Islands ${ }^{f}$ & f $\mathrm{ft}$ & None & 1 \\
\hline Mauritius $^{g}$ & $\mathrm{~m}$ & 2 & - \\
\hline India $^{\mathrm{h}}$ & $\mathrm{m}$ & 20 & 10 \\
\hline Nigeria $^{i}$ & $\mathrm{ft}$ & 100 & - \\
\hline Senegal $^{\mathrm{j}}$ & $\mathrm{m}$ & 40 & 5 \\
\hline United Kingdom $^{\mathrm{k}}$ & k m & 5 & - \\
\hline Vietnam $^{1}$ & $\mathrm{~m}$ & 1 & - \\
\hline \multicolumn{4}{|l|}{ United States $^{\mathrm{m}}$} \\
\hline Northeast & $\mathrm{ft}$ & 20 & 10 \\
\hline Mid-Atlantic & $\mathrm{ft}$ & 10 & 3 \\
\hline Southeast/Gulf & $\mathrm{ft}$ & 5 & 2 \\
\hline Pacific & $\mathrm{ft}$ & $20-40$ & - \\
\hline \multicolumn{4}{|c|}{ a See, e.g., Cambers (1992, p. 14) } \\
\hline \multicolumn{4}{|c|}{${ }^{b}$ See, e.g., Schnack et al. (1992, p. 279) } \\
\hline \multicolumn{4}{|c|}{${ }^{\mathrm{c}}$ See, e.g., El-Raey $(1995$, p. 191) } \\
\hline \multicolumn{4}{|c|}{ d See, e.g., Han et al. (1995, Figs 3, 5 \& 7) } \\
\hline \multicolumn{4}{|c|}{ e See, e.g., Huq et al. $(1995$, p. 45) } \\
\hline \multicolumn{4}{|c|}{${ }^{\mathrm{f}}$ See, e.g., Crawford et al. (1992, p. 50) } \\
\hline \multicolumn{4}{|c|}{${ }^{g}$ See, e.g., Jogoo $(1992$, p. 109) } \\
\hline \multicolumn{4}{|c|}{${ }^{\text {h }}$ See, e.g., Asthana et al. (1992, p. 197-198) } \\
\hline \multicolumn{4}{|c|}{${ }^{i}$ See, e.g., Awosika et al. (1992, p. 241) } \\
\hline \multicolumn{4}{|c|}{ j See, e.g., Niang et al. (1992, p. 411) } \\
\hline \multicolumn{4}{|c|}{${ }^{\mathrm{k}}$ Robert Nichols (pers. comm.) } \\
\hline \multicolumn{4}{|c|}{${ }^{1}$ Eastman \& Gold (1996) } \\
\hline \multicolumn{4}{|c|}{$\begin{array}{l}\text { mUSGS } 7.5^{\circ} \text { topographic maps. Specific regional water } \\
\text { resource agencies sometimes have better topography for } \\
\text { specific areas. For example, the South Florida Water } \\
\text { Management District has } 60 \mathrm{~cm}(2 \mathrm{ft}) \text { contours. Although } \\
\text { most topographic maps display contours in feet, some } \\
\text { recent maps for Maryland and a few southeastern states } \\
\text { use } 1 \mathrm{~m} \text { contours in a few locations }\end{array}$} \\
\hline
\end{tabular}

The problem of poor topographic information is not limited to the United States, as shown in Table 1. In the United Kingdom and Canada, maps tend to employ the $5 \mathrm{~m}$ contour. In much of the developing world, the contour interval is $10 \mathrm{~m}$ or more, and some nations even lack complete coverage. The one bright spot in all of this is that several of the very low-lying deltaic and small-island nations have $1 \mathrm{~m}$ topographic information, at least for the more populated areas.

\subsubsection{Benchmarks}

A second problem is that the elevations do not directly state how far the land is above sea level. In the United States, elevations are generally measured with 
respect to the National Geodetic Vertical Datum (NGVD) of 1929, which was originally meant to be a fixed reference plane. NGVD was set equal to the sea level of 1929 at specific reference stations along the North American coast. ${ }^{6}$ The reference 'plane' ${ }^{7}$ in all other locations was based on leveling techniques (i.e., surveying). As a result, even in 1929, NGVD was not sea level in areas where water levels diverge from the ideal plane. Since 1929, rising sea level and subsidence have caused sea level and NGVD to diverge 10 to $20 \mathrm{~cm}$ in most areas. ${ }^{8}$

The sinking land has also led to some confusion as to whether NGVD is a fixed or a moving reference plane. Consider a parcel of land that in 1929 was $1 \mathrm{~m}$ above both NGVD and sea level. If the sea rose $50 \mathrm{~cm}$, then this parcel would be only $50 \mathrm{~cm}$ above sea level, but it would remain $1 \mathrm{~m}$ above NGVD. But what happens if the land sinks $50 \mathrm{~cm}$ ? According to the National Geodetic Survey (NGS), NGVD does not move, and, hence, the land would be $50 \mathrm{~cm}$ above NGVD. ${ }^{9}$

In actual practice, both USGS and NOAA's National Ocean Service (NOS) often treat the sinking land as if the sea had risen. USGS has not, for example, revised its topographic maps along the entire mid-Atlantic coast to reflect the 10 to $15 \mathrm{~cm}$ in subsidence that has occurred throughout the region. ${ }^{10}$ The NOS 'published benchmark sheets' suggest that sea level at New York's Battery Park was $17 \mathrm{~cm}$ above NGVD in the early $1980 \mathrm{~s}^{11}$ which reflects the entire measured relative sea level rise that had occurred since 1929 at that location. ${ }^{12}$ The net effect of treating subsidence as if

\footnotetext{
${ }^{6}$ Mean sea level was held fixed at 26 gauge sites, 21 in the United States and 5 in Canada at the following locations: Father Point, Que.; Halifax, NS; Yarmouth, NS; Portland,

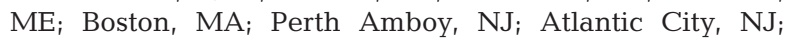
Annapolis, $\mathrm{MD}$; Old Point Comfort, VA; Norfolk, VA; Brunswick, GA; Fernandina, FL; St. Augustine, FL; Cedar Keys, FL; Pensacola, FL; Biloxi, MS; Galveston, TX; San Diego, CA; San Pedro, CA; Fort Stevens, OR; Seattle, WA; Anacortes, WA; Vancouver, $\mathrm{BC}_{i}$ and Prince Rupert, BC

${ }^{7}$ The term 'plane' is a misnomer because the Earth is not flat. But because the earth seems flat over small areas, the term is probably more descriptive than 'sphere'

${ }^{8}$ See, e.g., the National Oceanic and Atmospheric Administration's [NOAA] published benchmark sheet for Washington, DC (US Dept of Commerce 1987) which shows mean sea level to be about $20 \mathrm{~cm}(0.7 \mathrm{ft})$ above NGVD

${ }^{9}$ D. Zilkowski, National Geodetic Survey (pers. comm., February 2, 1998)

${ }^{10}$ USGS would revise this information if a small area sank significantly more than the surrounding area, because it could relevel the elevations back to 'stable' benchmarks. But when the entire region is subsiding, there is no benchmark against which this subsidence can be measured. Hence, USGS treats it as a rise in sea level

${ }^{11}$ The NOAA published benchmark sheets are to be found at http://www.opsd.nos.noaa.gov/bench.html

${ }^{12}$ See, e.g., Permanent Service for Mean Sea Level (1999)
}

sea level has risen is that, for all practical purposes, the NGVD benchmark sinks along with the land-at least in cases where subsidence is relatively modest. ${ }^{13}$

Recognizing the problems with the deteriorating benchmark, the USGS and the NGS are gradually converting to the use of the North American Vertical Datum (NAVD) of 1988. The reference plane associated with this benchmark is based on a single fixed site. Although this benchmark will eventually result in a more objective description of elevations, for those assessing the impacts of global warming, it adds another source of confusion. The printed USGS maps are still based on NGVD, yet some-but not all-of the digital elevation information refers to the distance above NAVD.

\subsection{Rationale for developing two types of maps}

Comprehensive assessments of sea level rise require accurate maps of the entire coastal zone. Unfortunately, such maps have been impossible given our budget limitations. Hence, we have undertaken separate projects to produce accurate maps and maps of the entire coastal zone.

Our relatively accurate maps will be based on an approach that has been gradually evolving since the late 1980s. That approach, sometimes called the 'SLAMM model'14 has been employed by several nationwide assessments. In each of those studies, a sample of $10 \%$ of the US coast was sufficient to estimate nationwide quantities, such as the loss of land, ${ }^{15}$ the cost of holding back the sea, the value of the land at risk to a rise in sea level, ${ }^{16}$ and the economic impact of sea level rise. ${ }^{17}$ This approach is also appropriate for assessments of relatively small areas, as well as studies whose primary objective was to illustrate the potential importance of an impact, such as the possible loss of habitat for shorebirds ${ }^{18}$ or fish. We elaborate further in Section 3.

\footnotetext{
${ }^{13}$ NOAA does consider the fact that benchmarks are sinking relative to the fixed reference plane in areas where the subsidence is more rapid, such as Galveston, TX. See, .e.g., the NOS Web page at http://www.opsd.nos.noaa.gov/bench/ tx_notice.html (cited April 1, 1999; contact NOS webmaster for currrent information) (which explained that the benchmarks were being recomputed). But even here the USGS maps are not being revised. Hence, the USGS maps and the NOAA benchmark sheets will be, effectively, assuming 2 different benchmark elevations

${ }^{14}$ The SLAMM model was developed as part of EPA's Sea Level Rise project and documented in detail by Park et al. (1989)

${ }^{15}$ See, e.g., Titus et al. (1991), who used the Park et al. model to estimate the amount of mainland areas that could potentially be inundated in a study estimating the loss of land from a rise in sea level, and the cost of holding back the sea
} 
Maps of larger areas are necessary for many purposes. Senior Administration officials, Congressmen, Governors, and the news media need a rough sense of the vulnerability of entire states. As a result, a map that fairly represents the total amount of land that could be lost in a given state is more useful than a map of a representative site, even if the latter map more precisely displays the impact on particular parcels of land. Similarly, researchers attempting to determine the vulnerability of a particular resource may find a rough map of an entire state more useful than a more accurate map of a few representative sites. In the latter case, the researcher must extrapolate a case study to the entire state, while in the former case one analyzes the entire state, albeit with poorer input data. We elaborate further in Sections 4 and 5 .

Both of our planned efforts rely on existing elevation data. Recognizing the need for improved elevation data, the NGS recently commissioned a National Height Modernization Study. The study considers a number of procedures based on remote sensing, both from airplanes and satellites. The report estimates that the LIDAR $^{19}$ technology, which has $95 \%$ accuracy within 6 in $(\sim 15.2 \mathrm{~cm})$, can be implemented for $\$ 200$ $\mathrm{km}^{-1}$ (NGS 1998). This technology has already been used for analyzing changes in glaciers and beaches (see, e.g., Sallenger et al. 1999). Nevertheless, using these technologies to map the coastal zone may be more difficult than using them to map glaciers and beaches, because the latter tend to be relatively bare, while coastal lands are often covered with trees, marsh grasses, buildings, and vehicles.

\footnotetext{
${ }^{16}$ See Yohe (1990), who used the Park et al. model for assumptions regarding the land at risk in a study estimating the cost of not holding back the sea

${ }^{17}$ See Yohe et al. (1996), who used the Park et al. model for assumptions regarding the land at risk in a study that compared the costs of holding back the sea with the value of land that would otherwise be lost, in a study that assumed that communities will follow the least expensive course of action

${ }^{18}$ See 'Climate Change Impacts on Coastal and Estuarine Systems in the Pacific Northwest' (which discusses the loss of habitat for shorebirds from a rise in sea level), Hector Galbraith, Stratus Consulting, Inc. Presentation at 'Wetlands and Global Climate Change' conference held at USGS Patuxent Wildlife Research Center, February 1-2, 2000, Laurel, MD

${ }^{19}$ LIDAR (light detection and ranging) is an optical counterpart to radar (radio detection and ranging). Radar works by bouncing pulses of radio-frequency energy against a target, LIDAR does the same with laser light. Precise timing of the time it takes for light to travel from the LIDAR unit to the ground and back can allow for precision measurement of the Earth's surface. See National Geodetic Survey p. 8-24
}

\section{LARGE SCALE MAPS (SMALL STUDY AREAS)}

\subsection{Previous studies}

Assessments of the impact of future sea level rise have generally dealt with the lack of elevation data by interpolating between the contour intervals. For example, Kana et al. (1984) digitized the elevation contours from topographic maps and employed a digital terrain model to estimate elevations in the area around Charleston, South Carolina. In a subsequent assessment of Charleston's coastal wetlands, Kana et al. (1986, 1988) suggested that future studies could infer elevations based on vegetation. Coastal wetland species are often best suited to a particular frequency of flooding. If one observes that a particular species dominates at a given location, then one can infer how often that location is flooded. If the tidal range is known, ${ }^{20}$ one can infer the elevation based on the frequency of flooding. For example, in the Charleston area, the low marsh species Spartina alterniflora is typically found at elevations (relative to mean sea level) that are 0.8 to 1.0 times the elevation of mean high water (Kana et al. 1986); so one can infer that wherever this species dominates, the land elevations must be just below mean high water.

As part of the EPA (1989) Report to Congress, Park et al. (1989) applied the procedure suggested by Kana et al. $(1986,1988)$ in a nationwide assessment of the potential loss of wet and dry land from a 50 to $200 \mathrm{~cm}$ rise in sea level. The study was based on 48 coastal sites equally spaced along the coast, comprising $10 \%$ of the coastal zone of the contiguous United States. Each site consisted of the area covered by 4 adjacent topographic maps. Using a $500 \mathrm{~m}$ grid, a subcontractor, the Indiana Remote Sensing Laboratory, digitized the contours from the topographic maps, and used a digital elevation model (DEM) to interpolate elevations. The subcontractor also analyzed LANDSAT multispectral imagery to provide information on vegetation type for each cell. Using that information, Park et al. identified low and high marsh areas. They then inferred elevations based on the mean tide range provided by the topographic map of a particular area. For areas above the high marsh, they used the elevations provided by the Remote Sensing Laboratory, which were interpolated between the shoreline and the first topographic contour. Based on the samples from the Park et al. analysis, the EPA developed its widely cited estimate that a $1 \mathrm{~m}$ rise in global sea level would inundate

\footnotetext{
${ }^{20}$ NOAA publishes the tide ranges for more than 1000 sites along with its published benchmark sheets. See Footnote 4. Topographic maps also provide estimates of tidal ranges
} 
$18000 \mathrm{~km}^{2}\left(7000 \mathrm{miles}^{-1}\right)$ of dry land, an area the size of Massachusetts. ${ }^{21}$

The EPA/Park et al. (1989) study had 3 deficiencies. First, it did not provide state-specific estimates, because it relied on a sample. Using elementary statistical sampling theory, the authors reported a $95 \%$ confidence interval for land loss: throughout the United States, 13000 to $27000 \mathrm{~km}^{2}$ of dry land, and 32 to $56 \%$ of the coastal wetlands, would be lost from a $1 \mathrm{~m}$ rise in sea level (Titus \& Greene 1989, Titus et al. 1991). As we discuss below in Section 4, the study did provide regional estimates, but they were rough at best, and based on a simple scaling of the results for the small number of sites in each region. ${ }^{22}$ The authors did not try to provide state-specific estimates, recognizing that extrapolating 1 or 2 sites to an entire state would have no statistical validity. (However, see Section 5.2, below, where we suggest a way by which the old Park et al. sample results might be combined with our maps of the entire coast to yield state-specific estimates of vulnerability.)

A second problem was that the $500 \mathrm{~m}$ grid size was too coarse for many purposes. Given the relatively small size of the case study areas, the $500 \mathrm{~m}$ cells resulted in maps that looked more like checkerboards than recognizable land formations. ${ }^{23}$ Even for purposes of developing aggregate estimates, the coarse grid overlooked some features. Barrier islands are often narrower than $500 \mathrm{~m}_{i}$ estuarine beaches and fringing wetlands are often only $10 \mathrm{~m}$ wide. With the exception of very flat areas, 1 or more elevation contours may be within $500 \mathrm{~m}$ of the shore; hence the poor resolution tended to represent poorly the elevation of land just above the high water mark.

Finally, while Park et al. (1989) used vegetation information to infer elevations of wetlands, they did not use this information to improve elevation estimates for the adjacent dry land. It would probably have been better to specify the elevation of the upper edge of the wetlands first, and treat the upper edge as simply another contour for the DEM to use. Such a procedure would have used the wetland information to improve estimates of the elevation of nearby dry land, as well as the wetlands themselves. Accurately estimating the elevation of land just inland of the wetlands is important, because that land is first to be inundated as the sea rises.

${ }^{21}$ See EPA (1989, p. 123 and Appendix B), and Titus et al. (1991, p. 187)

${ }^{22}$ For example, if a region had a total of 105 topographic $7.5^{\prime}$ quadrangles, and the sampled sites had a total of 15 quadrangles, then the authors multiplied the combine sample results by a scalar of $105 / 15=7$

${ }^{23}$ See Fig. 7, below, where we display our interpolations of the Park et al. maps

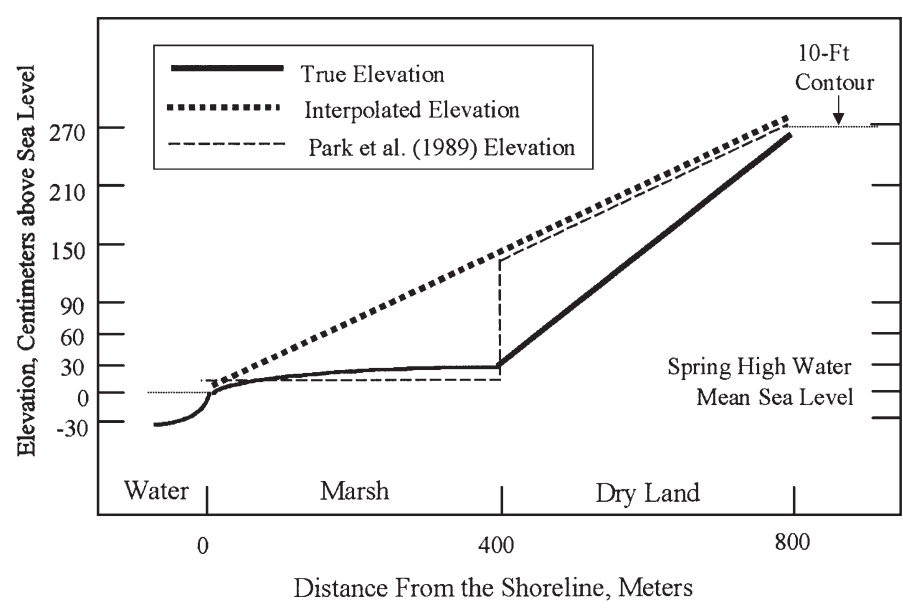

Fig. 1. Potential errors from interpolating elevations in coastal areas. Calculating land elevations by interpolating between

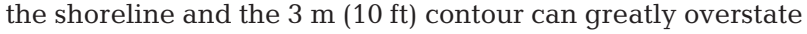
land elevations in coastal areas where a large area of wetlands causes the shore to follow a 'concave-up' profile. In this example, the upper edge of the marsh is $30 \mathrm{~cm}$ above sea level, while the interpolated elevation at that point is $135 \mathrm{~cm}$ above sea level. In this example, if the marsh were only a few meters inland of the $3 \mathrm{~m}(10 \mathrm{ft})$ contour, the interpolated elevation at the upper edge of the marsh would be close to $270 \mathrm{~cm}$. By using information on vegetation and known tidal ranges, Park et al. (1989) had much better estimates of wetland elevations. By interpolating between the upper edge of the wetlands and the $3 \mathrm{~m}$ (10 ft) contour, they also could have had much better dryland elevation estimates. Unfortunately, their dryland elevation estimates were based on interpolations between the contour and the shore. (Note: In this example, the $10 \mathrm{ft}$ contour is assumed to be $270 \mathrm{~cm}$ above mean sea level. Along much of the US coast, mean sea level is 10 to $30 \mathrm{~cm}$ above the NGVD)

Consider Fig. 1, which shows a typical coastal bay where the spring tidal range is $60 \mathrm{~cm}$ (i.e., mean spring high water is $30 \mathrm{~cm}$ above sea level), and the topographic map's $3 \mathrm{~m}$ (10 ft) contour is $2.7 \mathrm{~m}$ above mean sea level. ${ }^{24}$ In this example, the marsh is $400 \mathrm{~m}$ wide, while the $60,90,150$, and $270 \mathrm{~cm}$ elevation lines are $50,100,200$, and $400 \mathrm{~m}$ inland from the upper edge of the marsh; the profile of the dry land is a straight line. Fig. 1 illustrates the difference between 3 alternative models for estimating elevations between the $3 \mathrm{~m}$

\footnotetext{
${ }^{24}$ The elevation contours on topographic maps are generally measured with respect to the NGVD of 1929. Along most of the Atlantic Coast, mean sea level is 10 to $20 \mathrm{~cm}$ above the NGVD zero elevation, for 2 reasons. First, sea level has risen by 10 to $20 \mathrm{~cm}$ along much of the US coast since 1929. Second, even in 1929, the NGVD was not precisely at mean sea level in most areas. For a comparison of mean sea level with the NGVD elevation, see the published benchmark sheets of the Oceanographic and Products Services Division of the National Ocean Service at http://www.opsd.nos.noaa.gov/ bench.html
} 
(10 ft) contour and the shore: simple interpolation between the shore and the contour; the combination of simple interpolation and wetland data that Park et al. (1989) used; and the approach we now suggest. In this example, our suggested approach would accurately estimate the location of the 60,90 , and $150 \mathrm{~cm}$ contours by linearly interpolating between the upper edge of the marsh and the $3 \mathrm{~m} \mathrm{(10} \mathrm{ft)} \mathrm{contour.} \mathrm{An} \mathrm{interpolation}$

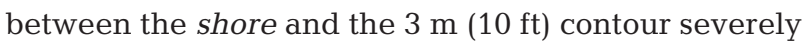
overestimates the elevation of both the marsh and much of the dry land. Although the Park et al. procedure provided a more accurate estimate of the wetland elevation, its estimates of dry land elevations were no better than the elevations from the pure interpolation approach.

The difference between these approaches illustrates an axiom of modeling: better data does not, by itself, always lead to a more accurate result. The simple linear DEM model in this case finds $80 \mathrm{~m}$ of land between 0 and $30 \mathrm{~cm}$ above high water, when in reality only $50 \mathrm{~m}$ of land lie within $30 \mathrm{~cm}$ of high water. However, the Park et al. (1989) model would find no land just above high water, because it uses the DEM linear interpolation results, which indicate that this land is 135 to $152 \mathrm{~cm}$ above sea level.

The practical importance of this modeling inconsistency was probably not very great in 1989 , because the primary objective was to determine the nationwide impact of a $100 \mathrm{~cm}$ rise in global sea level, which typically implied a $120 \mathrm{~cm}$ rise in relative sea level in most locations. In the southeastern United States, which has most of the land at risk, the lowest topographic contour

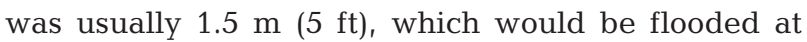
mean high water in most areas from a $120 \mathrm{~cm}$ rise in sea level. But as we consider smaller rises in sea level or analyze impacts in areas with less precise elevation data, these considerations become more important.

A final approach was developed by Leatherman et al. (1995), in recognition of their observation that, in developing nations, 'most maps only have 10- to 100-meter contour intervals, which are virtually useless when analyzing impacts of any reasonable sea level rise scenario. ${ }^{25}$ For regions with such poor information, Leatherman et al. recommended a system entitled 'Aerial Videotape-Assisted Vulnerability Analysis' (AVVA). This procedure requires one to obtain (1) aerial videotape of the coast, and (2) surveyed transects from a few sample locations. The analyst then uses the videotape to subjectively extrapolate transects to the entire coast.

The Leatherman et al. (1985) procedure is in many ways analogous to the Park et al. (1989) approach for estimating wetland elevations. Park et al. used remote

\footnotetext{
${ }^{25}$ Leatherman et al. (1995), p. 15
}

sensing data to extrapolate the basic transect information provided by surveys reported by Kana et al. (1986, 1988) (and others). By the same token, Leatherman et al. used what their own eyes could see on the videotape to extrapolate the surveyed transects.

The Leatherman et al. procedure is almost certainly less precise than the use of vegetation data along with known tidal ranges. The subjective nature of the approach does not, however, render it invalid. Although the human eye may be less accurate than a good contour map or remote sensing, a site visit or flyover can enable one to notice topographic features that would not be obvious from a map with wide contour intervals. Where the contour interval is $10 \mathrm{~m}$ and the first contour is $1000 \mathrm{~m}$ inland, the human eye can discern whether there is a 5 to $8 \mathrm{~m}$ bluff at the shore, or a wide area of low coastal wetlands, a distinction that is often beyond the capability of an elevation model. Furthermore, Leatherman et al. (1985) tested their approach on an area with known elevations, determined that the bias was not great, and concluded that the method is more accurate than linear interpolation from a $6 \mathrm{~m}(20 \mathrm{ft})$ contour. Thus, although the procedure does not necessarily provide good maps of the precise locations likely to be inundated, it can provide a useful estimate of the total amount of land that a nation could lose to a rising sea. Estimates using this technique provide the only estimates of the land vulnerable to a rise in sea level in Nigeria, Senegal, Argentina, Uruguay, and Venezuela. $^{26}$

\subsection{Improved modeled elevations}

In the last decade, technological improvements have made it possible to improve upon the procedures employed by the EPA Report to Congress. Faster computational speeds and cheaper storage make it possible to reduce cell sizes by an order of magnitude. Furthermore, for a large and increasing part of the coastal zone, individual researchers no longer need to interpolate and digitize topographic maps. The USGS has digitized its $7.5^{\circ}$ maps $_{1}{ }^{27}$ run its DEM, and made the results available to the public, with elevations usually

\footnotetext{
${ }^{26}$ See Nichols et al. (1995, p. 26) (who explain that the AVVA approach had been applied in studies conducted by the (now defunct) University of Maryland Laboratory for Coastal Research in cooperation with and the following in-country experts: I. Niang of Senegal; L. Awosika and C. E. Ibe of Nigeria; E. Schnack of Argentina; J. Arismendi of Venezuela; and C. Volonte of Uruguay). See also IPCC (1996b, p. 308, Table 9-3) (which shows a list of all nationwide studies that estimated the total land lost from a rise in sea level, and the same studies of Nigeria, Senegal, Argentina, Uruguay, and Venezuela as the only quantitative studies of those nations)
} 
rounded to the nearest foot $(30 \mathrm{~cm})$ and with a grid size of $30 \mathrm{~m}$. Finally, rather than rely on raw spectral signature data from satellites, one can locate coastal wetlands using the National Wetlands Inventory (NWI) developed by the US Fish and Wildlife Service.

Over the next few years, we plan to gradually redo the 1989 EPA Report to Congress. This time, instead of mapping a sample, we plan to map the entire coastal zone. Instead of $500 \mathrm{~m}$ cells, we will use $30 \mathrm{~m}$ cells. Rather than relying on ad hoc digital terrain models for interpolation, we will use the published $7.5^{\circ} \mathrm{DEM}$ results. And instead of relying on LANDSAT spectral imagery, we will use the NWI. Although the details of our planned shoreline modeling effort are outside the scope of this paper, let us briefly examine the elevation component of our planned effort.

Fig. 2 depicts coastal elevations around Bolivar Flats in Galveston Bay, Texas. ${ }^{28}$ In this area, the wetland classes tend to be approximately $-15 \mathrm{~cm}(-0.5 \mathrm{ft}),+9 \mathrm{~cm}$ $(+0.3 \mathrm{ft})$, and $+18 \mathrm{~cm}(+0.6 \mathrm{ft})$ NGVD, for the mudflat, low marsh, and high/transitional marsh, respectively. Although we do not examine bathymetry, open water areas occur where the land surface is below mean low water, that is, about $-50 \mathrm{~cm}(-1.7 \mathrm{ft})$ NGVD. In Fig. 2a, the various shades illustrate the DEM elevations, which the USGS rounds to the nearest foot $(30 \mathrm{~cm})$; the dark lines show the outlines of various wetland classes. In this area, the printed topographic maps use $5 \mathrm{ft}$ contours; hence elevations between 0 and $1.5 \mathrm{~m}$ ( 0 and $5 \mathrm{ft}$ ) are based on the modeled interpolation. As one would expect, the model tends to treat the typical profile as roughly a straight line between 0 and $1.5 \mathrm{~m}(0$ and $5 \mathrm{ft})$, as evidenced by the roughly equal distances between the various contours with $30 \mathrm{~cm}(1 \mathrm{ft})$ increments. $^{29}$ Fig. $2 \mathrm{~b}$ shows the elevations one gets from overlaying the DEM estimates with the typical local elevations for various wetland categories identified by the NWI data. Because mean spring high water is approximately $18 \mathrm{~cm}(0.6 \mathrm{ft})$ above NGVD, the upper edge of the marsh is a good estimate of the $18 \mathrm{~cm}$ contour.

Including the NWI data leads to the types of effects noted in our discussion of Fig. 1: The wetlands tend to extend farther inland than one would expect from a linear interpolation. As a result, the actual $18 \mathrm{~cm}(0.6 \mathrm{ft})$

\footnotetext{
${ }^{27}$ The quality of the input data for the 7.5' DEM varies, however. In some cases, USGS digitized the topographic contours. In other cases, they merely recorded elevations along discrete contours. In still other cases, they used aerial photographs, but with a lower resolution than the photos used to create the printed topographic maps

${ }^{28}$ These maps were prepared by Russ Jones of Stratus Consulting, Inc., as part of the study described in Footnote 18, supra

${ }^{29}$ To keep the number of shades manageable, we do not show the $3.5 \mathrm{ft}$ contour
}
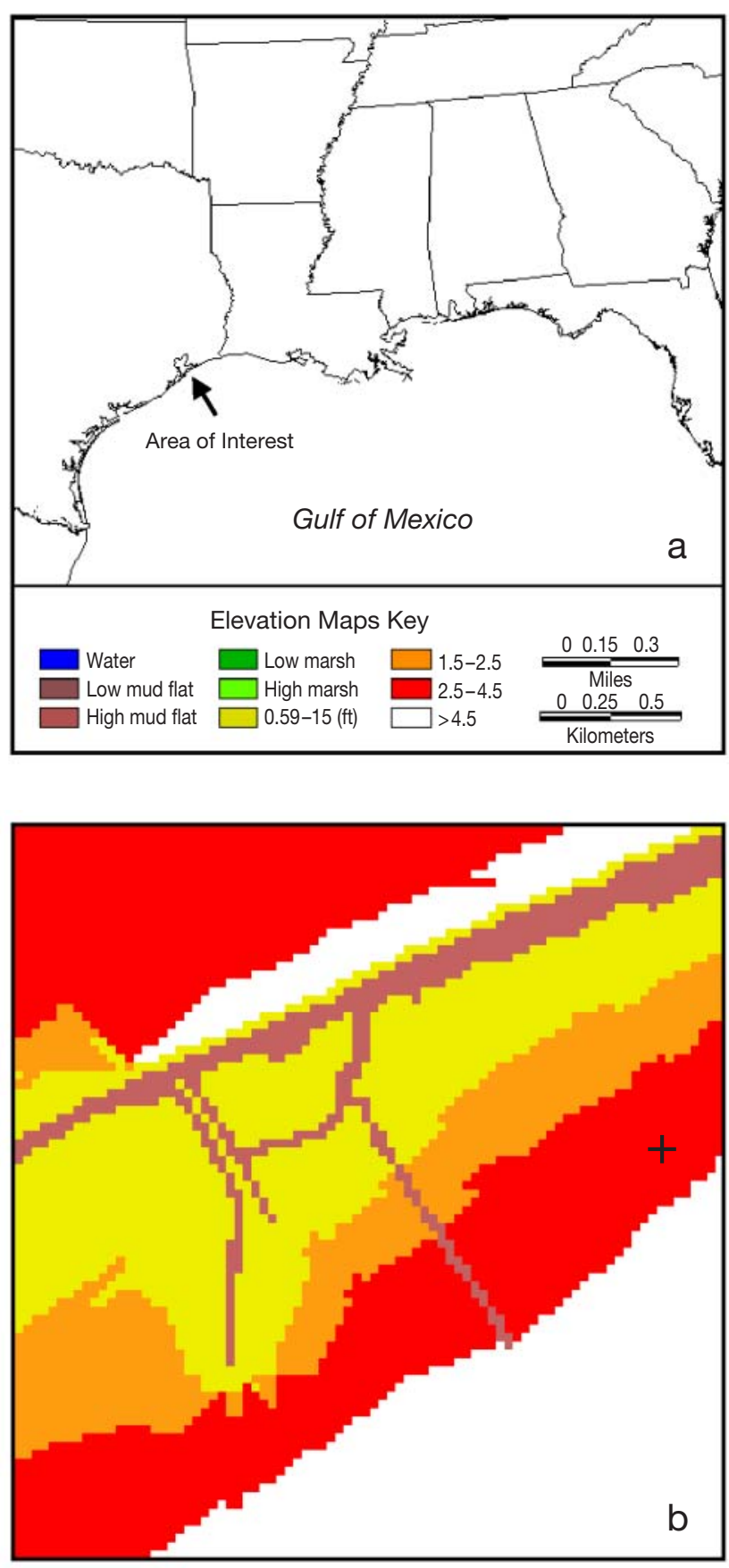

Fig. 2. (Above and facing page) Alternative ways of characterizing elevations using DEM and NWI; Bolivar Peninsula, Galveston, Texas. (a) Locator map and color key. (b) Using the raw output from the DEM. (c) Using the National Wetland Inventory data for wetlands and, as in map a, using the DEM data in areas that are not wetlands. (d) Using the same wetland-based elevation estimates, but interpolating elevations between the upper edge of the marsh and the elevation representing the first contour from the printed topographic map, which in this case is the $5 \mathrm{ft}(1.5 \mathrm{~m})$ contour 

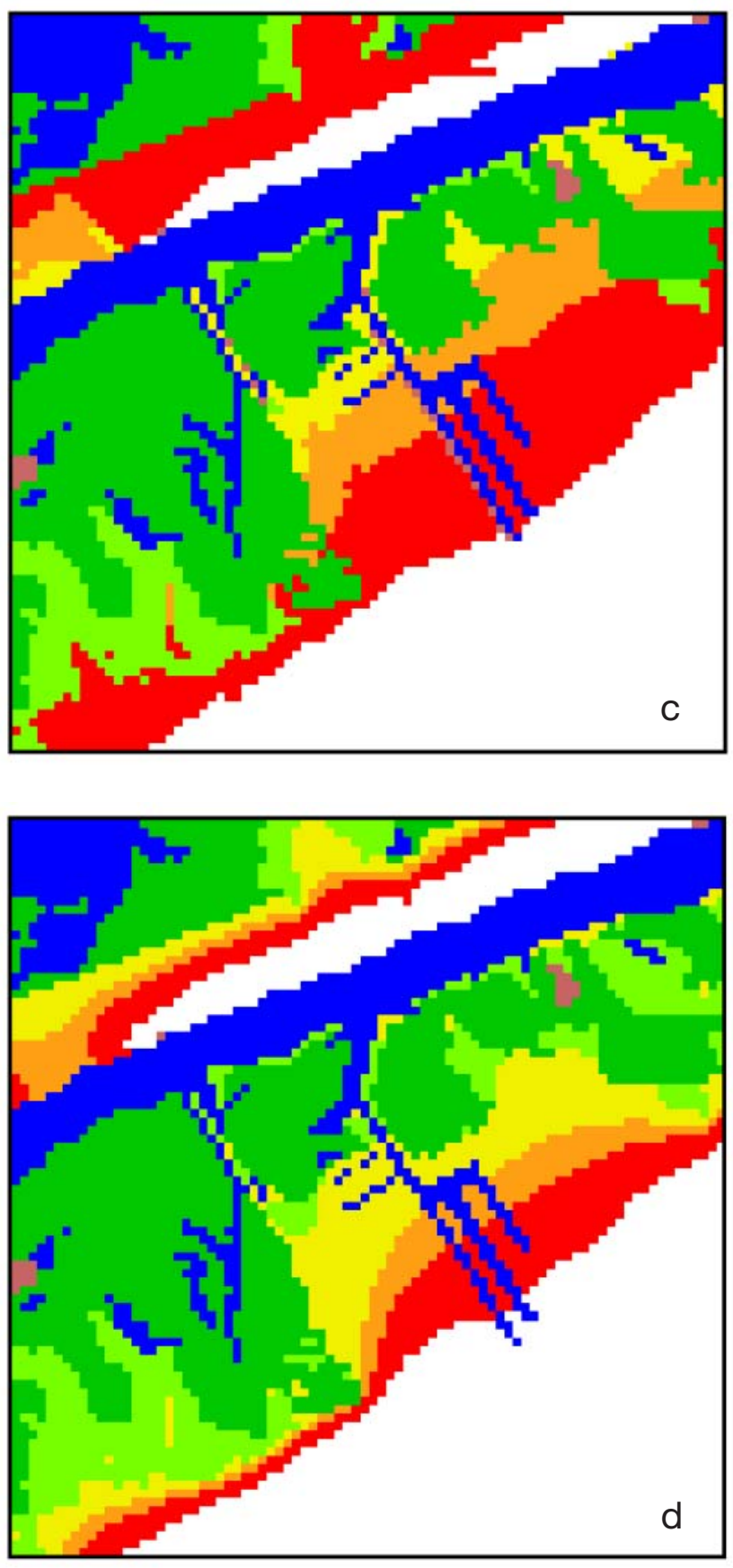

contour crosses areas that the DEM alone assumed to have elevations of 60 to $120 \mathrm{~cm}$ ( 2 to $4 \mathrm{ft}$ ). Thus, the old Park et al. (1989) procedure of simply overlaying the NWI data would - in those areas - tend to assume a small bluff above the marsh and a complete absence of land within about $50 \mathrm{~cm}$ (1 or $2 \mathrm{ft}$ ) of the high water mark. The net effect for the entire site is to reduce the amount of land within 30 to $60 \mathrm{~cm}$ (1 to $2 \mathrm{ft}$ ) of the high water mark by more than $50 \% .^{30}$

Fig. 2c shows our attempt to use the wetland information to reinterpolate the 1.5, 2.5, and (not shown)
Table 2. Elevation distributions (ha) for the case study area in Flake Quadrangle, Bolivar Peninsula, Galveston, Texas. Fig. 2 depicts the study area. Elevations are with respect to the NGVD, which is above sea level in this region; hence some wetlands have negative elevations. No interpol.: method employed by Park et al. (1989) for determining elevations of dry land below the first topographic contour. With interpol.: elevations estimated by linearly interpolating between the upper edge of the wetlands and the first topographic contour

\begin{tabular}{|c|c|c|c|c|}
\hline $\begin{array}{l}\text { Elevation } \\
(\mathrm{ft})\end{array}$ & $\begin{array}{l}\text { Classi- } \\
\text { fication }\end{array}$ & $\begin{array}{l}\text { DEM } \\
\text { only }\end{array}$ & $\begin{array}{l}\text { DEM ar } \\
\text { No. interpol. }\end{array}$ & $\begin{array}{l}\text { nd NWI } \\
\text { With interpol. }\end{array}$ \\
\hline$>4.5$ & Dry & 413 & 403 & 446 \\
\hline $3.5-4.5$ & Dry & 230 & 186 & 62 \\
\hline $2.5-3.5$ & Dry & 279 & 120 & 63 \\
\hline $1.5-2.5$ & Dry & 213 & 95 & 79 \\
\hline $0.59-1.5$ & Dry & $385^{a}$ & 54 & 157 \\
\hline $0.5-0.59$ & High marsh & a & 95 & 151 \\
\hline $0.2-0.5$ & Low marsh & a & 414 & 414 \\
\hline$-0.2-+0.2$ & Mudflat & a & 10 & 6 \\
\hline$<-0.2$ & Water & $106^{\mathrm{a}}$ & 248 & 248 \\
\hline Total & & 1625 & 1625 & 1625 \\
\hline \multicolumn{5}{|c|}{$\begin{array}{l}\text { The DEM-only data finds } 106 \text { ha below } 0.5 \mathrm{ft} \text { and } 385 \text { ha } \\
\text { between } 0.5 \text { and } 1.5 \mathrm{ft} \text {. The DEM does not distinguish be- } \\
\text { tween the various classifications below }+0.5 \mathrm{ft} \text {, nor does } \\
\text { it distinguish between above and below the elevation of } \\
0.59 \mathrm{ft}\end{array}$} \\
\hline
\end{tabular}

$3.5 \mathrm{ft}$ contours, that is, the elevations between the upper edge of the wetlands and the lowest topographic contour. Time constraints prevented us from using the same model and underlying data that the USGS used; instead, we simply used the interpolation feature available in ARC/Info. As Table 2 shows, the net effect of the interpolation is to increase the area of land just above the wetland elevation, at the expense of land

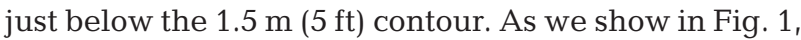
this seems to be a preferable result: We may never be comfortable estimating the land within 30 to $60 \mathrm{~cm}$ of mean spring high water based on interpolation; however, interpolation is a reasonable first-order assumption. By contrast, under the previous approach, our estimate of the dry land inundated by a small rise in sea level is functionally dependent ${ }^{31}$ on the discrepancy between the NWI data and the DEM.

\footnotetext{
${ }^{30} \mathrm{~A}$ second noticeable effect is that the NWI data picks up various features that the DEM overlooks, such as the extra finger canals. The additional features may show up because they were created after the topographic map was last updated, or because the DEM was based on coarser-resolution input data

${ }^{31} \mathrm{In}$ the old procedure, if mean high water is $30 \mathrm{~cm}(1 \mathrm{ft})$ above NGVD, then the amount of land within $30 \mathrm{~cm}$ of mean high water would be equal to the amount of land between 30 and $60 \mathrm{~cm}$ according to the DEM, minus the amount of wetlands below $30 \mathrm{~cm}$ that the DEM erroneously assumes to be between 30 and $60 \mathrm{~cm}$ (without adding in the amount of land that really is between 30 and $60 \mathrm{~cm}$ that the DEM erroneously attributed to other elevations)
} 


\section{SMALL-SCALE MAPS (LARGE AREAS)}

\subsection{Previous studies}

The absence of small-scale maps was a principal factor motivating this study. The only previous efforts that we know about are an early effort by Schneider \& Chen (1980) and a recent effort by the USGS. The Schneider \& Chen study examined the area that would be potentially inundated by a 5 to $8 \mathrm{~m}$ (15 to $25 \mathrm{ft}$ ) rise in sea level, based on printed USGS maps. In response to a 1997 request from the White House, Vince Caruso $^{32}$ of the USGS created a map of South Florida, using data from the USGS DEM, superimposed on NOAA shoreline information. ${ }^{33}$

We decided at the outset to omit the Pacific and Arctic coasts of the United States, for 3 reasons. First, elevation data is poor - in many cases USGS maps still use

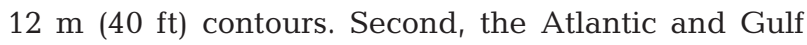
coasts of the United States account for $95 \%$ of the land within $1 \mathrm{~m}$ of mean high water (EPA 1989). Finally, with the exception of Hawaii, hurricanes and other severe storm surges are rare in the developed areas. ${ }^{34}$ To the extent that these coasts are vulnerable to sea level rise, erosion - rather than inundation and flooding - is the most likely problem; and a map illustrating land close to sea level sheds little if any light on erosion.

\subsection{Methods}

The most practical way to obtain maps within our budget was to employ the published elevations estimated by the DEMs of the USGS. The USGS makes DEMs available at the $7.5^{\prime}, 30^{\prime}$, and $1^{\circ}$ scales. $^{35}$ The most obvious choice would be the $7.5^{\prime}$ DEMs, which are based on the printed topographic maps that generally are used in large-scale mapping efforts. Unfortunately, the US coastal zone has more than 2000 of these 'quads'. These digital maps were not available for all locations, ${ }^{36}$ with particularly poor availability along Chesapeake Bay and Delaware Bay. Even where

\footnotetext{
${ }^{32}$ Vince Caruso authored the USGS DEM standards and is generally recognized as the USGS's primary expert on DEM ${ }^{33}$ See Office of Science and Technology Policy (1997, p. 16). The report erroneously states that one-third of the Everglades is less than 12 inches $(350 \mathrm{~cm})$ above sea level. As shown by both the USGS map and our map of Florida, probably about one-third of the Everglades is below $1.5 \mathrm{~m}$. Nevertheless, about half of Everglades National Park consists of mangroves, which are within 30 to $60 \mathrm{~cm}$ of sea level. As of April 1, 1999, this map was also posted on the White House Web page at http://www.whitehouse.gov/Initiatives/ Climate/Figure16.gif and http://www.whitehouse.gov/Initiatives/Climate/vulnerabilities.html. (With the change in administration, the document was moved to: http://clinton4. nara.gov/Initiatives/Climate/content.html
}

these digital maps are available, the cost of processing and analyzing this data was likely to be a few hundred dollars per map-or more.

Using the $1^{\circ}$ was more practical. These data were available for the entire US Atlantic and Gulf coasts. Moreover, the individual tiles were $1 / 2^{\circ} \times 1^{\circ}$, so that these 2 coasts could be entirely covered with only 90 individual tiles of data.

The accuracy of the $1^{\circ} \mathrm{DEM}$ is limited by partial reliance on small-scale (low-resolution) maps, rounding error, and other artifacts of the modeling approach used by the USGS. The $1^{\circ} \mathrm{DEM}$ uses elevation data from cartographic sources collected from several different map series ranging from the $7.5^{\prime}$ series through the $1^{\circ}$ series. ${ }^{37}$ Although the $7.5^{\prime}$ maps generally have contours of 1.5 or $3 \mathrm{~m} \mathrm{(5} \mathrm{or} 10 \mathrm{ft}$ ), the contours on the $1^{\circ}$ maps are often 10 or $20 \mathrm{~m}$, which sharply limit the ability of the model to locate a 1 or $2 \mathrm{~m}$ contour. Moreover, the reported elevations are rounded to the nearest meter. All areas with an estimated elevation less than $50 \mathrm{~cm}$, whether land or water, are shown to have an elevation of zero. Even where the model accurately calculates all elevations, the true shoreline will not be depicted in areas with wide expanses of very low wetlands, because the model's 'shoreline' is the $50 \mathrm{~cm}$ contour. ${ }^{38}$ In addition to this vertical rounding error, the model also has a type of horizontal rounding error: the DEM assumes some peninsulas and islands to be open water, and some embayments to be dry land.

\footnotetext{
${ }^{34}$ Landsea (1999) explains: 'Hurricanes ... in the Northeast Pacific almost never hit the U.S. ... There are two main reasons. The first is that hurricanes tend to move toward the west-northwest after they form in the tropical and subtropical latitudes. ... A second factor is the difference in water temperatures along the U.S. east and west coasts. Along the U.S. east coast, the Gulf Stream provides a source of warm waters to help maintain the hurricane. However, along the U.S. west coast, the ocean temperatures rarely get above the lower 70s.... So for the occasional Northeast Pacific hurricane that does track back toward the U.S. west coast, the cooler waters can quickly reduce the strength of the storm.'

${ }^{35}$ See, e.g., USGS (1999)

${ }^{36}$ The source of this statement was the set of state-specific links provided at the USGS DEM status Web site http:// mcmcweb.er.usgs.gov/status/dem_stat.html shown in April 1998. By the time the reader checks this Web site, DEM results may be available for more sites. Nevertheless, in many cases those results are poor, reflecting the so-called 'DEM level 1' rather than the more accurate 'DEM level 2'. See, e.g., National Environmental Trust (1998, p. 23) (as of January 1, 1999, found at http://www.envirotrust.com/ edgar.html) displaying a map purporting to show the $1 \mathrm{~m}$ contour around Edgartown, MA, based on DEM level 1. The DEM's $1 \mathrm{~m}$ contour generally follows, but is occasionally inland of, the $3 \mathrm{~m}(10 \mathrm{ft})$ contour in the printed map, which is the source of the DEM data

${ }^{37}$ See USGS (1999)
} 


\subsection{Our initial draft maps}

To be useful to most people, maps of coastal states must have recognizable shorelines. As in the Caruso/USGS study, we used the NOAA (1999) shoreline data ${ }^{39}$ series for the existing shoreline, and the DEM for elevations. The NOAA and DEM shorelines are very different: along the US Atlantic and Gulf coasts, more than $40000 \mathrm{~km}^{2}$ of land are shown by the NOAA data to be land but shown by the DEM to have zero elevation-twice the size of the area that the DEM shows to have an elevation of $1 \mathrm{~m}$. Because dikes do not generally protect these areas, they could not possibly have a zero elevation; so we had to assign an elevation to these areas. ${ }^{40}$

Initially, we simply assumed that all land above the NOAA shoreline but below the DEM shoreline has an elevation between mean sea level and $50 \mathrm{~cm}$ above the NGVD. By definition, this assumption is accurate in those areas where the DEM is accurate: Because the DEM rounds elevations to the nearest meter, such low land would show up with zero elevation. In areas where the DEM misses peninsulas and islands, however, this assumption falsely implies that large areas of high ground are below the $50 \mathrm{~cm}$ contour.

\subsection{Quality control used to prepare the final product}

Given the occasional inaccuracies of the DEM, we had to ensure that discrepancies between the DEM and NOAA shorelines did not create a significant bias

\footnotetext{
${ }^{38}$ The methods used to create these DEMs have several limitations. They are created by interpolation from known elevations drawn from underlying hard-copy maps. Data points are gathered along transects or profiles running in one direction (north-south) and automated interpolation processes are used to estimate elevations for a regular lattice of points covering the area of the DEM. For these DEMs, the modeled points are some 70 to $90 \mathrm{~m}$ apart, but significantly larger features can be misrepresented due to 'smoothing' in the interpolation process. Source maps also vary in vintage, and variations between adjacent DEMs are apparent. See USGS (1999)

39 'NOAA's Medium Resolution Digital Vector Shoreline is a high-quality, Geographic Information System-ready, generaluse digital vector data set created by the Strategic Environmental Assessments (SEA) Division of NOAA's Office of Ocean Resources Conservation and Assessment. Compiled from hundreds of NOAA coast charts, this product comprises over 75000 nautical miles of coastline (nearly 2.5 million vertices), representing the entire conterminous United States of America, Alaska, the Hawaiian Islands.' See NOAA (2000)

${ }^{40}$ For a discussion of the Caruso approach to this problem, which USGS used to prepare the Florida map for the White House, see 'Maps of Lands Close to Sea Level,' the extended documentation of this project available from the author
}

in the amount of land assumed to have a very low elevation.

We decided that the final maps would suppress the $50 \mathrm{~cm}$ contour and only display the 1.5 and $3.5 \mathrm{~m}$ contours. We would have liked to display a $50 \mathrm{~cm}$ contour, but the topographic maps against which we were comparing the DEM maps did not have the necessary precision to do so. ${ }^{41}$ The $1.5 \mathrm{~m}$ contour, by contrast, is essentially the same as the $5 \mathrm{ft}$ contour, which is available for most areas along the Gulf and southeastern Atlantic coasts. The $3.5 \mathrm{~m}$ elevation is likewise close to the $10 \mathrm{ft}$ contour, which appears on most maps along the mid-Atlantic coast, as well as those maps that have $5 \mathrm{ft}$ contours.

We also decided not to alter the results for New England. Refinements of the initial DEM maps of this area would be relatively difficult, and would not substantially change the maps. The $7.5^{\circ}$ USGS maps in New England tend to use 3 and $6 \mathrm{~m} \mathrm{(10} \mathrm{and} 20 \mathrm{ft}$ ) contours, and hence would not really tell us which maps are in error. Moreover, the initial DEM maps correctly showed that this region has relatively little low land.

Our quality control approach had the following 4 steps:

Step 1. Inspect areas where the DEM shows the $50 \mathrm{~cm}$ contour to be well inland of the NOAA shoreline. First, we looked for areas where the initial maps projected far more land below the $50 \mathrm{~cm}$ contour than the amount of land between the 50 and $150 \mathrm{~cm}$ contours, that is, areas where the $50 \mathrm{~cm}$ DEM contour is relatively close to the $150 \mathrm{~cm}$ DEM contour but a long way inland of the NOAA shoreline. This is a good sign that for some reason the DEM is totally missing the shore or treating the necks between 2 rivers as open water. ${ }^{42}$ Wherever this occurred, ${ }^{43}$ we checked the topographic map, and made any necessary corrections by hand. ${ }^{44}$

\footnotetext{
${ }^{41}$ Some city drainage maps have $30 \mathrm{~cm}(1 \mathrm{ft})$ contours, and one might infer elevations of $50 \mathrm{~cm}$ in those areas where wetland vegetation happens to extend to that elevation. But that would apply to only a few areas

${ }^{42}$ Initial spot checks revealed that in most areas where the DEM missed the shoreline and showed an order of magnitude more land below the $0.5 \mathrm{~m}$ contour than between the 1.5 and $3.5 \mathrm{~m}$ contours (e.g., Long Island, Chesapeake Bay, Delaware Bay) all of the contour information was poor. In those areas that showed comparable amounts of land below between the 1.5 and $3.5 \mathrm{~m}$ contours, and below the 1.5 and/or $0.5 \mathrm{~m}$ contours, (northern North Carolina, eastern Texas), the contours themselves were reasonable. Louisiana was an exception: with its rapid subsidence and low tidal range, thousands of square kilometers of wetlands really are below the $50 \mathrm{~cm}$ contour

${ }^{43}$ Major corrections were made for the Eastern Shore of Maryland, the Western Shore of Chesapeake Bay, especially Virginia, and both sides of Delaware Bay. Changes were also made along Long Island back barrier bays and far a few areas along the Albemarle and Pamlico Sounds in North Carolina ${ }^{44}$ These corrections typically had an error of approximately 1 to $4 \mathrm{~km}$
} 
These blatant errors were prominent along most of Delaware Bay and Chesapeake Bay, where the shorelines had to be completely redrawn by hand.

Step 2. Review by state governments. Next we sent the maps out to key coastal zone officials in each state, on the assumption that they would notice any blatant errors. ${ }^{45}$ As it turned out, only half provided comments and none noted any serious errors. They did, however, indicate a strong interest in obtaining these maps for their public information purposes.

Step 3. Inspect topographic maps wherever the initial maps suggested a large loss of land. Finally, we spent 3 additional days comparing our initial DEM maps with USGS topographic maps. ${ }^{46}$ Rather than performing random checks, we devoted most of our efforts to areas where we suspected the problems might be greatest. In the case of Florida, our results virtually duplicated the map that USGS prepared for the White House, although the USGS map covered only the southern part of the peninsula. ${ }^{47}$ Hence, with the exception of Miami and the Florida Keys, we merely compared our map with the USGS 1:100000 scale maps for the state. These maps generally depict a $5 \mathrm{~m}$ contour; but their 1, 2, and $3 \mathrm{~m}$ spot elevation measurements were generally consistent with our contours.

We also compared our maps to the 1:100000 scale maps of Texas, which fortunately provide the $2.5 \mathrm{~m}$ contour in most of the areas with the greatest amount of low land. Only a few minor changes were made for Florida, while Texas required about 10 changes from low to higher ground accounting for about $5 \%$ of the land below the $1.5 \mathrm{~m}$ contour. We made no changes to Louisiana, which is commonly known to have thousands of square kilometers of land below the $1.5 \mathrm{~m}$ contour (see, e.g., Louisiana Wetland Protection Panel 1987).

For Georgia, North and South Carolina, Virginia, Maryland, Delaware, New Jersey and New York, we examined about $85 \%$ of the 1:24000 scale (7.5') topographic maps corresponding to areas where the initial

\footnotetext{
${ }^{45}$ We assumed that state coastal management agencies were likely to notice blatant errors because many of their employees are intimately familiar with these areas, and because they sometimes have access to other types of elevation data, including wetland maps, flood insurance rate maps, and topographic maps produced by local municipal drainage departments. Representatives from New Jersey, Maryland, South Carolina, North Carolina and Louisiana indicated that the maps look accurate enough

${ }^{46}$ We spent these 3 days at the USGS map store in the headquarters building of the US Department of Interior, the parent agency of the USGS

${ }^{47}$ The USGS treated the depicted contour as $1 \mathrm{~m}$ above sea level, whereas we treat it as $1.5 \mathrm{~m}$ above the NGVD (about $1.3 \mathrm{~m}$ above sea level)
}

maps showed more than $5 \%$ of the area to be below the 3.5 m contour; the remaining $15 \%$ were not immediately available. Changes were minor for North Carolina, except for the area around the Dismal Swamp near the Virginia border. For Georgia, the DEM incorrectly estimated a number of freshwater swamps with actual elevations of 3 to $6 \mathrm{~m}$ to have an elevation of 1.5 to $3 \mathrm{~m}$. Along the Georgia and New York shores, as well as the ocean-coast portions of New Jersey, Delaware, Maryland, and Virginia, about $25 \%$ of the topographic maps revealed that the DEM $1 \mathrm{~m}$ contour is much too far inland. As Table 3 (below) shows, the quality control had the greatest impact on areas where the initial draft maps showed a large amount of land to be below the $50 \mathrm{~cm}$ contour. The hand editing reduced the amount of land below the $1.5 \mathrm{~m}$ contour by 40 to $50 \%$ in Virginia, Maryland, Delaware, and New York, and about $20 \%$ in New Jersey and Texas.

Step 4. Hand-edit the maps. We printed out a $60 \times$ $100 \mathrm{~cm}$ version of the initial DEM map for each state, with a grid representing the boundaries of the USGS 7.5' maps. Wherever the modeled contours looked roughly the same as those depicted by the topographic map, we left the initial map unchanged. Otherwise, we made free-hand drawings of the 5 and $10 \mathrm{ft}$ contours (depicted in the topographic map) onto our grid map, which we then digitized. Given the limited time spent on each of the 200 topographic maps that induced a hand edit, our error is probably between 10 and 30\% of the width of the particular land form being drawn, with the larger percentage error occurring with narrow islands and peninsulas. In the case of areas where the initial maps incorrectly attributed the major portion of an entire landform to be very low, correcting the map to accurately show the area to be above the contour would generally result in a minimal error.

\subsection{The maps}

Figs 3 to 6 show our maps of the land below the 1.5 and $3.5 \mathrm{~m}$ contours at 3 different scales. Fig. 3 shows the entire Atlantic and Gulf coasts. At this scale, 4 areas show up with large contiguous areas close to sea level: (1) coastal Louisiana (as well as the portion of Texas east of Galveston Bay), (2) South Florida, (3) North Carolina's Pamlico-Albemarle Peninsula, and (4) Dorchester County, Maryland, along the Eastern Shore of Chesapeake Bay. The map of the Gulf Coast (Fig. 4), at twice the scale, provides a clearer picture of the shorelines, but largely conveys the same information about the location of this region's lowest lands. (The peer reviewers of this article examined maps at scales similar to Figs $5 \& 6$ for all of the coastal states from New York to Texas. Although space limitations 


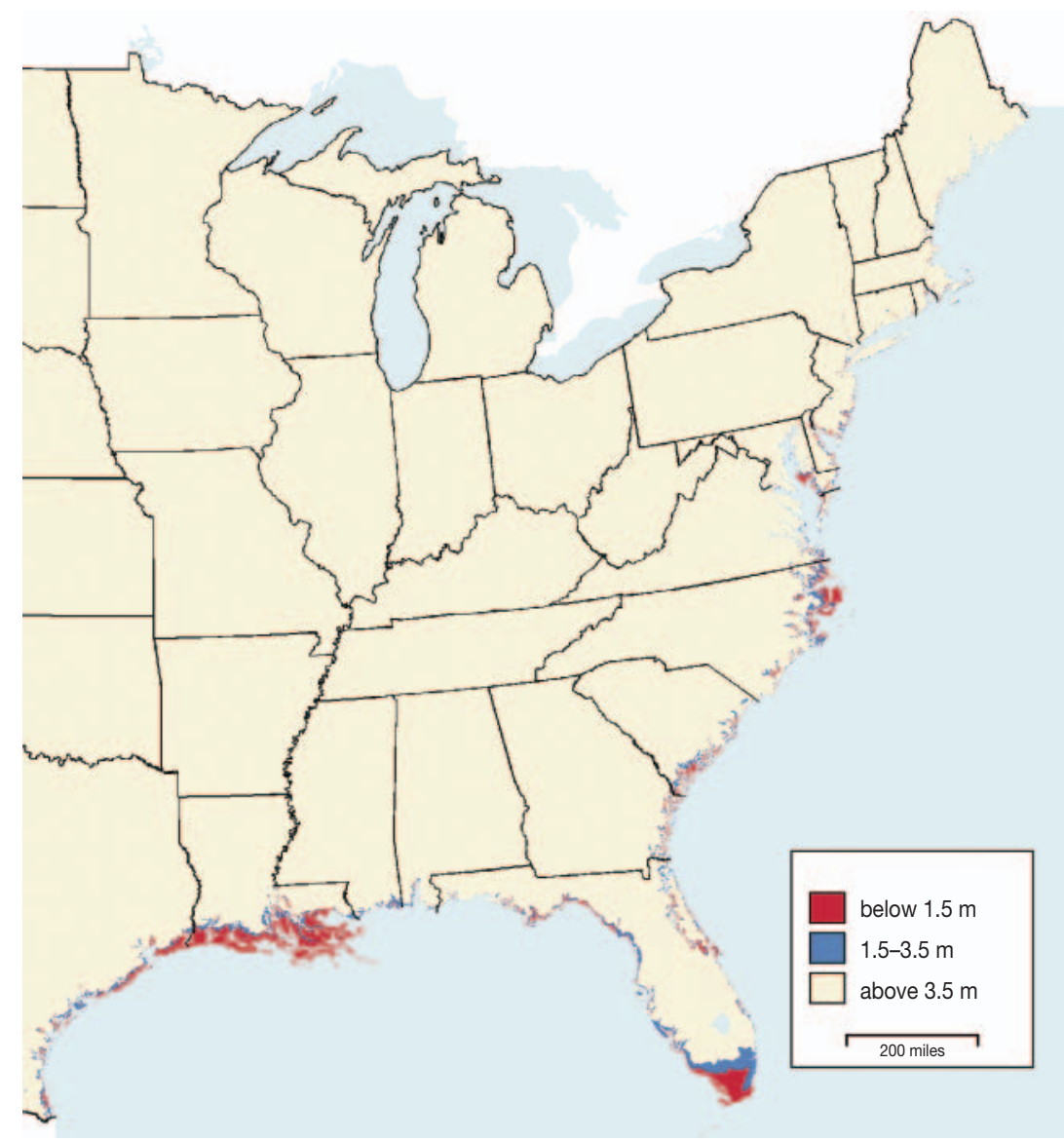

Fig. 3. Lands close to sea level: US Atlantic and Gulf Coasts. 1 mile $=\sim 1.6 \mathrm{~km}$
Albemarle Peninsula). Moreover, the entire North Carolina coast north of Cape Lookout has a substantial amount of land between the 1.5 and $3.5 \mathrm{~m}$ (5 and $10 \mathrm{ft}$ ) contours. ${ }^{49}$ The map of the Chesapeake Bay region shows the greatest amounts of low land in Dorchester County, Maryland; however the $1.5 \mathrm{~m}$ contour extends several kilometers inland along the other southern counties of Maryland's Eastern Shore, as well as Virginia's Accomac County. Along Delaware Bay, the $1.5 \mathrm{~m}$ contour is also several kilometers inland. Because the estuary has a spring tidal range close to $3 \mathrm{~m}$, most of the land below the $1.5 \mathrm{~m}$ contour is tidal wetland along Delaware Bay. By contrast, along Chesapeake Bay, Pamlico Sound and Albemarle Sound, the tidal ranges are much less than $1 \mathrm{~m}$, and hence those areas have considerable dry land below the $1.5 \mathrm{~m}$ contour, some of it inhabited and much of it cultivated.

Given the 1:250000 scale of the underlying maps upon which the DEM was based, we do not think that it would be prudent to display prevent those maps from being published here, they are available from the authors. $)^{48}$

Figs 5 \& 6 highlight North Carolina and Chesapeake Bay, respectively, at a scale approximately 10 times that of the national map. While the peninsula between Pamlico and Albemarle Sounds has the greatest

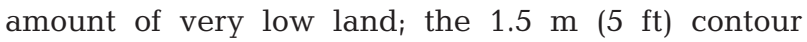
extends almost $25 \mathrm{~km}$ inland in Pamlico County (the peninsula immediately to the south of the Pamlico-
${ }^{48}$ Maps are available at http://www.epa.gov/globalwarming/ publications/impacts/sealevel/maps/

${ }^{49}$ When displaying these maps for readers accustomed to imperial units, we recommend referring to these contours as the 5 to $10 \mathrm{ft}$ contours, even though the correct conversions are 4.9 and $11.5 \mathrm{ft}$, respectively. The elevation estimates are too imprecise for displaying more than 1 significant digit. Moreover, for the most part, the DEM relied on 5 and $10 \mathrm{ft}$ contours in the underlying printed topographic maps

Fig. 4. Lands close to sea level: US Gulf Coast
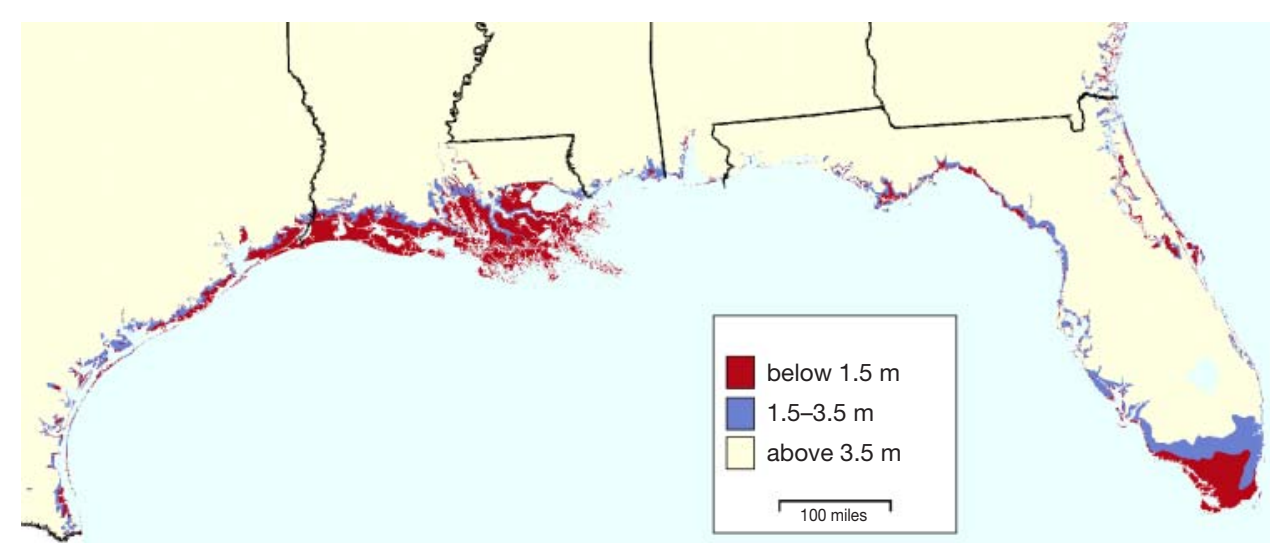


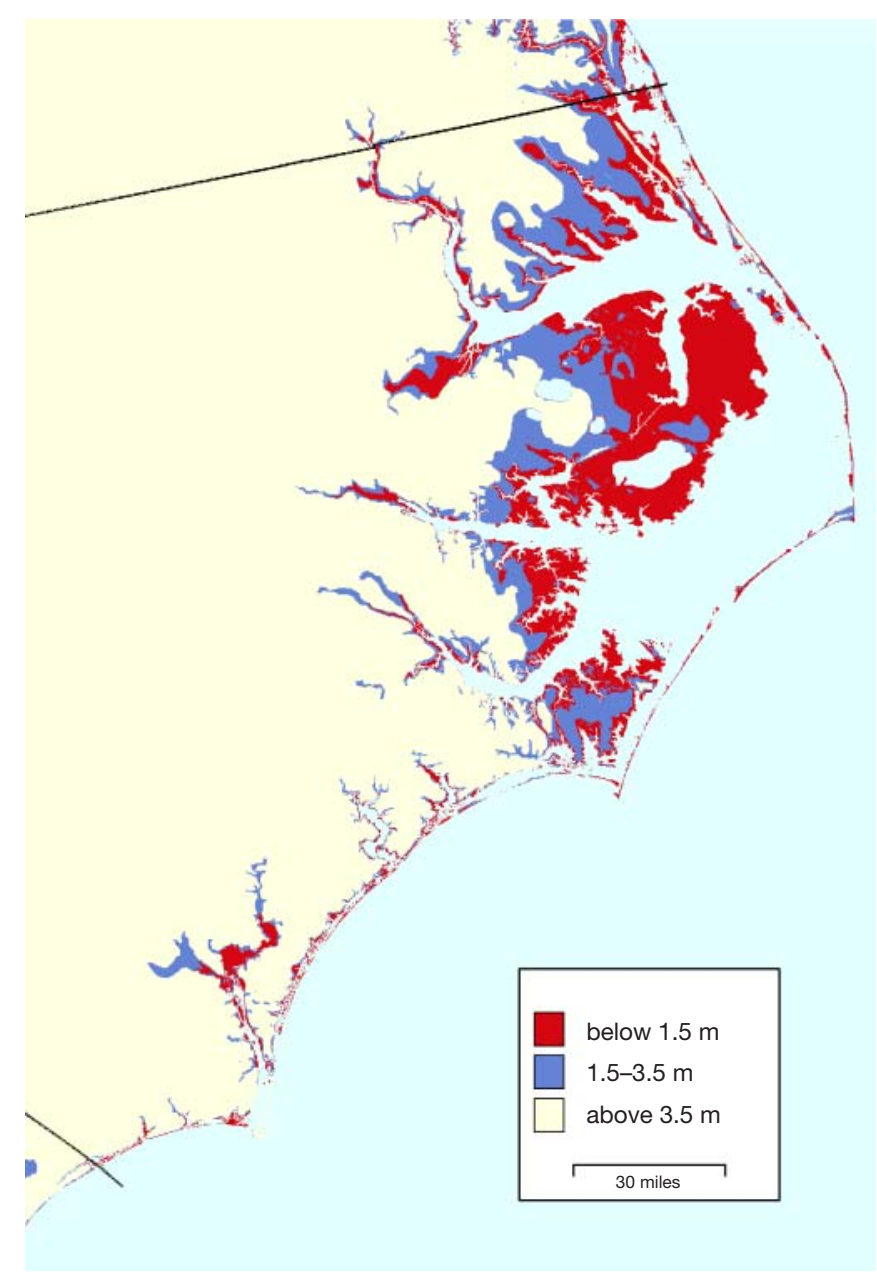

Fig. 5. Lands close to sea level: North Carolina

our results at scales larger than the state level-at least for the purpose of communicating and analyzing the risks of sea level rise. Case studies of particular areas (e.g., Kana et al. 1984) usually include maps based on higher resolution, and often consider risk factors other than elevation, such as erosion, flooding, and wetland accretion. Those maps are more likely to be reliable - and to be presented in a context that allows the reader to draw substantive conclusions. Nevertheless, we do display an example map at a larger scale, but only for the purpose of providing insight about how our maps compare with those from other studies.

Fig. 7 shows 4 maps of the area around Charleston, South Carolina: a map projecting future shorelines by Kana et al. (1984); interpolation of the grid cell maps from the SLAMM model by Park et al. (1989), for a $50 \mathrm{~cm}$ rise and a $100 \mathrm{~cm}$ rise; and our DEM. The 'low' and 'high' scenarios from the Kana et al. map roughly represent the same 1.5 and $3.5 \mathrm{~m}$ elevations as those illustrated in our DEM map. ${ }^{50}$ Both of these maps agree that the City of Charleston (the peninsula to the lower

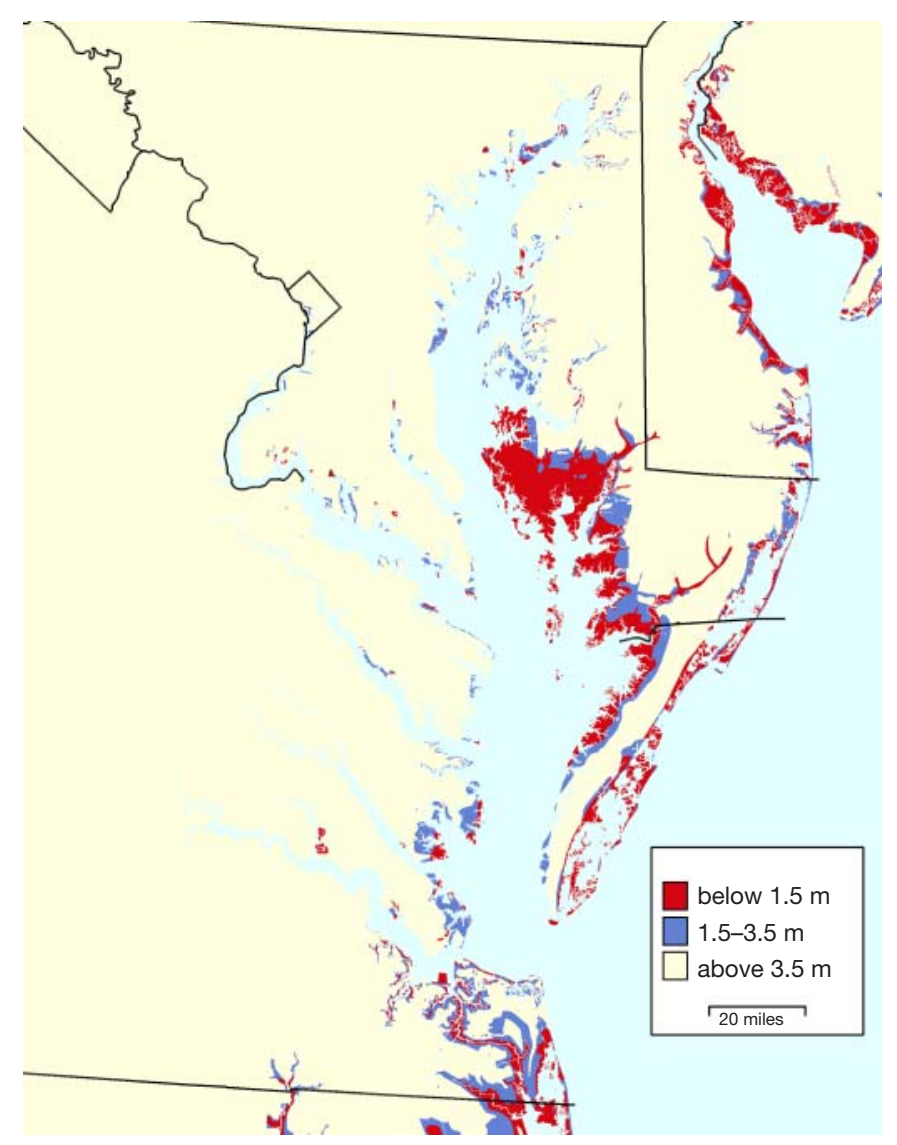

Fig. 6. Lands close to sea level: Chesapeake and Delaware Bays

left) is almost entirely above the $1.5 \mathrm{~m}$ contour, except for a low area on the east side. The maps also agree that much of the city is below the $3.5 \mathrm{~m}$ contour, which implies that with even a modest rise the city would experience increased flooding. Similarly, both maps agree that the peninsula to the northeast of Charleston is largely below the $1.5 \mathrm{~m}$ contour. The 2 maps are in agreement on most of the other key features.

Comparing our DEM map with the maps from Park et al. (1989) reveals that the wetlands identified by Park et al. largely track the $1.5 \mathrm{~m}$ contour from our DEM model. This is a pleasant surprise, given the absence of wetland information in the DEM. On the Charleston Peninsula, the Park et al. map picks up wetlands on both the east and west sides; although those wetland areas are smaller than the area that Kana et al. found below mean spring high water. The only significant feature that the Park et al. map missed is the peninsula to the northeast of Charleston, which

\footnotetext{
${ }^{50}$ The scenarios represented relative sea level rises of 87 and $239 \mathrm{~cm}$, respectively, over the 1980 level. See Kana et al. (1984, Table 4-1). Spring high water was about $1 \mathrm{~m}$ above NGVD in Charleston. See, e.g., Kana et al. (1986)
} 
SLAMM erroneously assumed to be relatively high ground. The Park et al. maps also reveal very little land within $30 \mathrm{~cm}$ above mean spring high water, confirming the concerns we expressed in Section 2 regarding the need to interpolate between the wetlands and the first elevation contour when using wetland data to infer elevations.

Our comparison of the 3 maps supports our initial hypothesis that the DEM maps provide a useful graphical representation of lands close to sea level. Nevertheless, the comparison also implies that we should be reluctant to distribute maps from this data set at this scale for reasons other than model validation: the overall correspondence looks reasonable, and when this area is reduced by a factor of 10 as part of a map of the state, it is very reasonable. However, at the scale displayed in Fig. 7, residents cannot help but try to determine the elevations of their own homes - and these maps are not precise enough for that purpose.

Table 3. Amounts $\left(\mathrm{km}^{2}\right)$ of low land implied by various map data sets

\begin{tabular}{|c|c|c|c|c|c|c|}
\hline \multirow{2}{*}{ State } & \multicolumn{3}{|c|}{$0<$ Elevation $<1.5 \mathrm{~m}$} & \multicolumn{3}{|c|}{$1.5 \mathrm{~m}<$ Elevation $<3.5 \mathrm{~m}$} \\
\hline & $\begin{array}{l}\text { DEM } \\
\text { only }^{\text {a }}\end{array}$ & $\begin{array}{l}\text { With } \\
\text { NOAA }^{b}\end{array}$ & $\begin{array}{l}\text { With } \\
\text { edit }^{c}\end{array}$ & $\begin{array}{l}\text { DEM } \\
\text { only }^{\mathrm{d}}\end{array}$ & $\begin{array}{l}\text { With } \\
\text { NOAA }^{\mathrm{e}}\end{array}$ & $\begin{array}{l}\text { With } \\
\text { edit }\end{array}$ \\
\hline $\mathrm{AL}$ & 157.7 & 194.7 & - & 383.6 & 354.6 & - \\
\hline CT & 107.7 & 63.0 & - & 67.6 & 48.6 & - \\
\hline DC & 1.3 & 6.8 & 1.5 & 2.3 & 2.3 & 4.0 \\
\hline $\mathrm{DE}$ & 125.1 & 645.8 & 387.8 & 254.1 & 243.9 & 172.0 \\
\hline FL & 7473.9 & 12248.8 & 12250.8 & 12956.4 & 12827.1 & 12742.9 \\
\hline GA & 385.9 & 1471.3 & 1742.6 & 2077.9 & 2028.1 & 1078.3 \\
\hline LA & 4852.6 & 24724.7 & - & 4410.5 & 4345.2 & - \\
\hline MA & 299.4 & 364.7 & - & 409.5 & 375.0 & - \\
\hline MD & 364.7 & 2944.5 & 1547.1 & 799.3 & 764.4 & 806.1 \\
\hline ME & 293.4 & 382.9 & - & 289.6 & 176.1 & - \\
\hline MS & 83.1 & 173.2 & - & 844.3 & 824.1 & - \\
\hline $\mathrm{NC}$ & 2007.5 & 6102.9 & 5835.9 & 3963.5 & 3936.8 & 3864.6 \\
\hline $\mathrm{NH}$ & 27.5 & 42.4 & - & 21.0 & 20.0 & - \\
\hline NJ & 297.1 & 1394.5 & 1083.0 & 1000.5 & 962.9 & 637.8 \\
\hline NY & 252.0 & 581.4 & 239.9 & 181.6 & 152.7 & 265.8 \\
\hline PA & 11.4 & 52.3 & 2.5 & 44.8 & 36.9 & 2.5 \\
\hline RI & 147.4 & 121.9 & - & 68.1 & 61.7 & - \\
\hline $\mathrm{SC}$ & 370.4 & 2354.7 & 2333.7 & 2593.1 & 2568.5 & 2401.7 \\
\hline TX & 2428.6 & 5237.3 & 5177.7 & 4430.4 & 4345.1 & 4213.2 \\
\hline VA & 374.3 & 2456.1 & 968.5 & 1292.7 & 1251.0 & 1041.4 \\
\hline Total & 20061.0 & 61564.0 & 57638.6 & 36091.0 & 35324.9 & 33435.7 \\
\hline \multicolumn{7}{|c|}{$\begin{array}{l}\text { b Area of land within } 1.5 \mathrm{~m} \text { of sea level, according to the initial draft maps; } \\
\text { that is, the area that (1) is land according to the NOAA shoreline data, and } \\
\text { (2) has an elevation of either } 0 \text { or } 1 \text { according to the DEM. Equal to a , plus } \\
\text { areas where DEM says } 0 \mathrm{~m} \text { and NOAA says land (i.e., the area that the } \\
\text { initial maps treated as land below the } 50 \mathrm{~cm} \text { contour), minus areas where } \\
\text { NOAA says water and DEM says } 1 \mathrm{~m}\end{array}$} \\
\hline $\begin{array}{l}{ }^{\mathrm{c}} \text { The } \\
\text { velop } \\
{ }^{\mathrm{d}} \text { Area } \\
{ }^{\mathrm{e}} \text { Area } \\
\text { draft }\end{array}$ & $\begin{array}{l}\text { area of lan } \\
\text { of land } v \\
\text { of and be } \\
\text { maps; tha }\end{array}$ & $\begin{array}{l}\text { within } 1 . \\
\text {-editing } t \\
\text { ween } 1.5 \\
\text { is, the pol }\end{array}$ & $\begin{array}{l}\mathrm{m} \text { of sea l } \\
\text { e initial d } \\
\text { tion of ei } \\
\text { d } 3.5 \mathrm{~m} \mathrm{a} \\
\text { on of lanc }\end{array}$ & $\begin{array}{l}\text { according } \\
\text { aps, as di } \\
\text { or } 3 \mathrm{~m} \mathrm{c} \\
\text { ea level } \\
\text { ribed in }{ }^{\mathrm{d}}\end{array}$ & $\begin{array}{l}\text { o our final } \\
\text { cussed in } \\
\text { cording to } \\
\text { cording to } \\
\text { hat NOAA }\end{array}$ & $\begin{array}{l}\text { naps, de- } \\
\text { ection } 2.2 \\
\text { the DEM } \\
\text { the initial } \\
\text { calls land }\end{array}$ \\
\hline
\end{tabular}

\subsection{Quantitative results: methodological implications}

Our primary motivation for producing maps of lands close to sea level was the expressed need by policy makers for graphical representations of the land that could be affected by a rise in sea level. The accompanying quantitative results may also be useful (1) because in some situations it may be more practical to cite an estimate of the area of low land than to display a map, and (2) because a consideration of the area estimates may provide insights into the methods that were employed by the analysis. We now examine the latter methodological implications, deferring the substantive implications until Section 5.

Table 3 displays the area of land close to sea level estimated by the various steps of our analysis, for 19 coastal states and the District of Columbia. The first column shows the amount of land that the DEM alone estimated to be between 0.5 and $1.5 \mathrm{~m}$ above the vertical datum (NGVD). The second column shows the amount of land below $1.5 \mathrm{~m}$ according to our initial draft maps, that is, the land below $1.5 \mathrm{~m}$ when one overlays the NOAA shoreline data and DEM results. Thus, the difference between the first two columns can be viewed as (a) the land below $50 \mathrm{~cm}$, (b) plus the additional low land overlooked by the large-scale DEM, (c) minus open water areas that the DEM incorrectly assumes to be land between 50 and $150 \mathrm{~cm}$ (NGVD).

The use of the NOAA shoreline data triples the estimate of the land below the $1.5 \mathrm{~m}$ contour, with the greatest percentage increases in Louisiana, North Carolina, Maryland, and Virginia. Although the percentage differences are less for Texas and Florida, the use of the NOAA data adds more than $2000 \mathrm{~km}^{2}$ of low land for both of these states. The effect is not surprising, given the large amount of coastal wetlands and the large amount of wetlands found in areas where the tidal range is less than 60 to $100 \mathrm{~cm}$. Because the high water mark is thus only 30 to $50 \mathrm{~cm}$ above sea level, wetlands are at similar elevations and hence are low enough for the DEM to round their elevations to zero.

The third column provides the area estimates for states where we made corrections by hand. The hand-edits reduced the estimated amount of low 


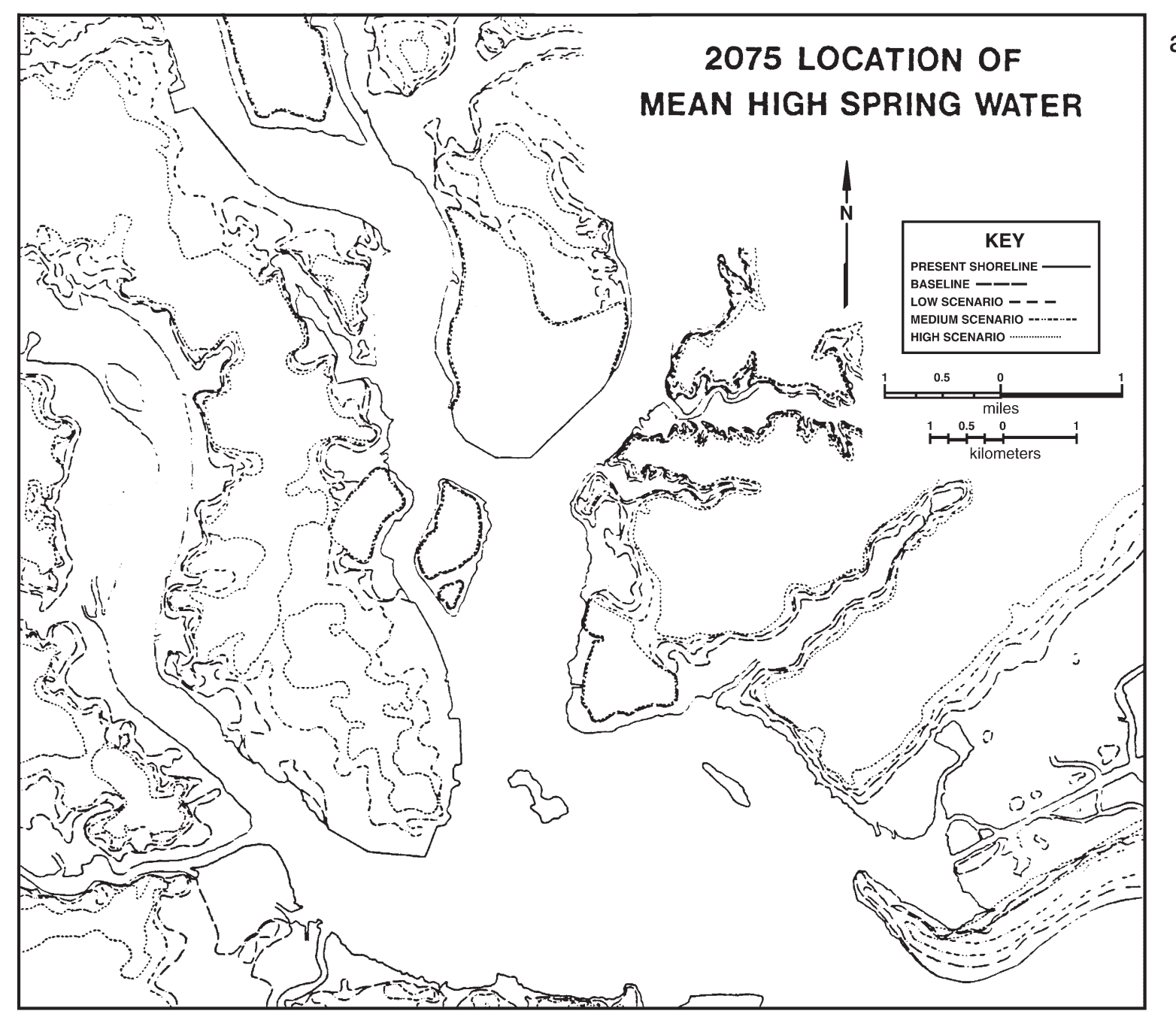

Fig. 7. (Above and next 3 pages) Maps showing lands close to sea level in the area of Charleston, South Carolina, from 3 studies. (a) Map from Kana et al. (1984). (b,c) Interpolated results from Park et al. (1989) for (b) $0.5 \mathrm{~m}$ and (c) $1.0 \mathrm{~m}$ rises in sea level. (d) Our DEM map of lands close to sea level

land for every state where the edits were made. The reductions of low land resulting from the hand-edits were greatest for the states in which adding the NOAA data caused the greatest increases in the amount of low land. The simplest explanation for this tendency inclufes the following: (1) in many states, the DEM had a landward bias in its location of the shoreline; (2) in such areas, overlaying the DEM elevations with the more accurate NOAA shoreline data identifies additional low land; (3) but at the same time, by mislocating the shoreline, the DEM also estimated some inland areas to be lower than they truly are, which was corrected by the hand-editing; (4) finally, the landward bias of the DEM shoreline tended to understate the land below $150 \mathrm{~cm}$ because (i) shore profiles tend to be concave-up, and (ii) given the large amount of wetlands below $50 \mathrm{~cm}$, the area below $150 \mathrm{~cm}$ is substan- tially greater than the area between 50 and $150 \mathrm{~cm}$. The 1 exception to this tendency was Louisiana. Even though inclusion of the NOAA shoreline data substantially increased our estimate of the amount of low land, the $1.5 \mathrm{~m}$ contour from the DEM was fairly accurate. The simplest explanation is that in this case, a large amount of low wetlands were assumed by the DEM to be below the $50 \mathrm{~cm}$ contour, and hence rounded to zero elevation. As a result, the DEM shoreline was well inland of the true shore, even though the $1.5 \mathrm{~m}$ contour had no such bias.

A second reason to examine the quantitative results is to shed light on the following question: How accurate are our maps? Table 4 provides a rough consistency check with the existing literature. The first column displays the total amount of land that our maps depict as below the $1.5 \mathrm{~m}$ contour, for each of the 6 


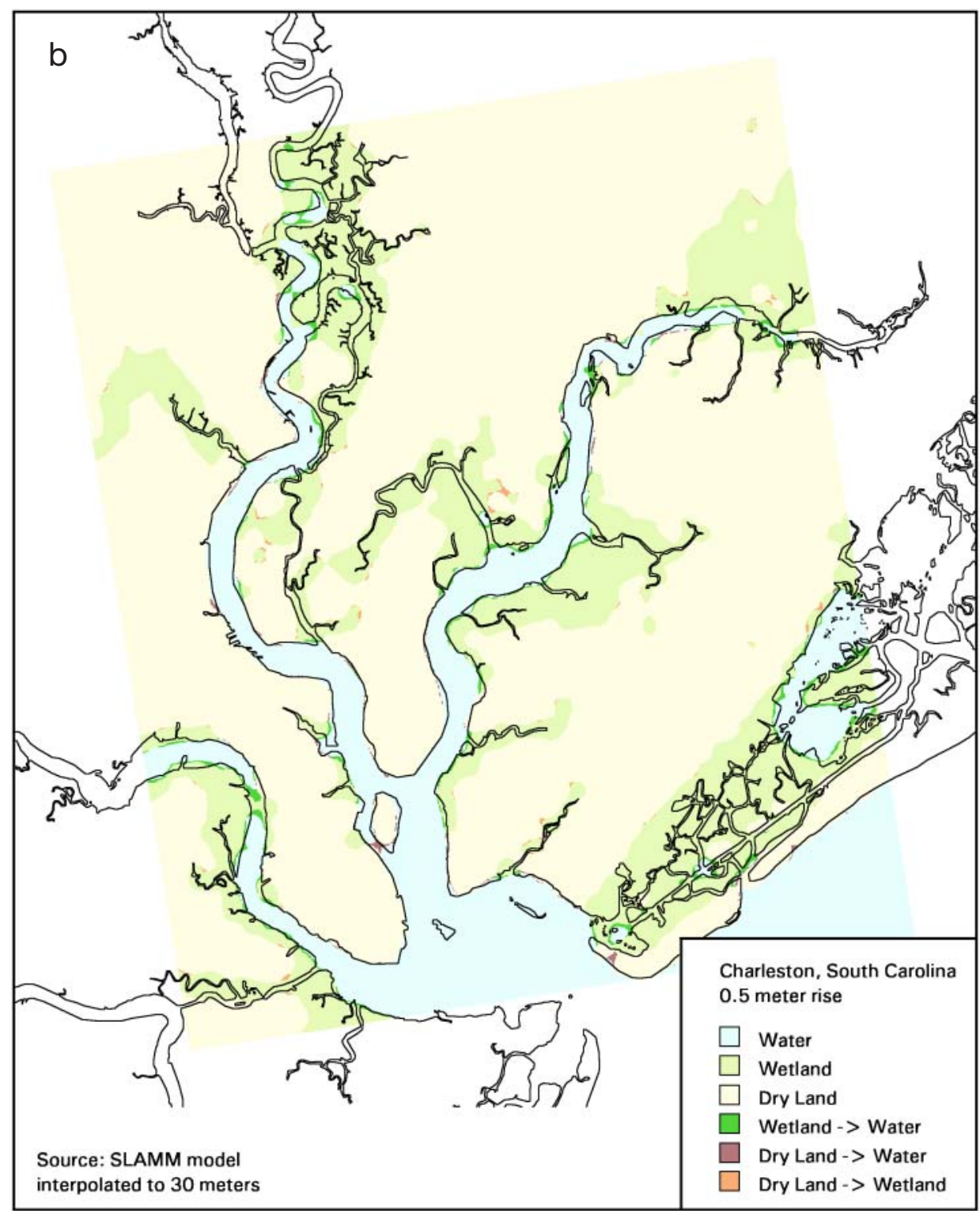

Fig. 7 (continued)

Atlantic and Gulf coast regions for which results were reported in the 1989 EPA Report to Congress. ${ }^{51}$ The second and third columns display the best estimates and standard deviations of the land loss estimates from the EPA Report to Congress. Our results are within 1 standard deviation of the EPA Report to Congress for all of the regions except for Louisiana and part of Florida. In these two states, our results suggest that there is far more land close to sea level than implied by the EPA Report to Congress.

${ }^{51}$ See Titus \& Greene (1989) (analyzing results from Park et al. 1989). A more concise summary of this analysis appears in Titus et al. (1991)
In the case of Louisiana, our maps depict $25000 \mathrm{~km}^{2}$ below the $1.5 \mathrm{~m}$ contour, about $50 \%$ more than the estimate from the EPA Report to Congress. The most likely explanation is that both our maps and our tabulations disregarded small lakes and ponds, treating them as land. In a study estimating the historic land loss in Louisiana, Dunbar et al. (1992) examined most of the quadrangles within the state's coastal plain, which covered an area of $47000 \mathrm{~km}^{2}$, and estimated that the examined quadrangles include approximately $18000 \mathrm{~km}^{2}$ of land. Our tabulations for the Louisiana coastal plain are based on the assumption that the same quadrangles have $28000 \mathrm{~km}^{2}$ of land. Given our $50 \%$ overstatement of the portion of the coastal zone 


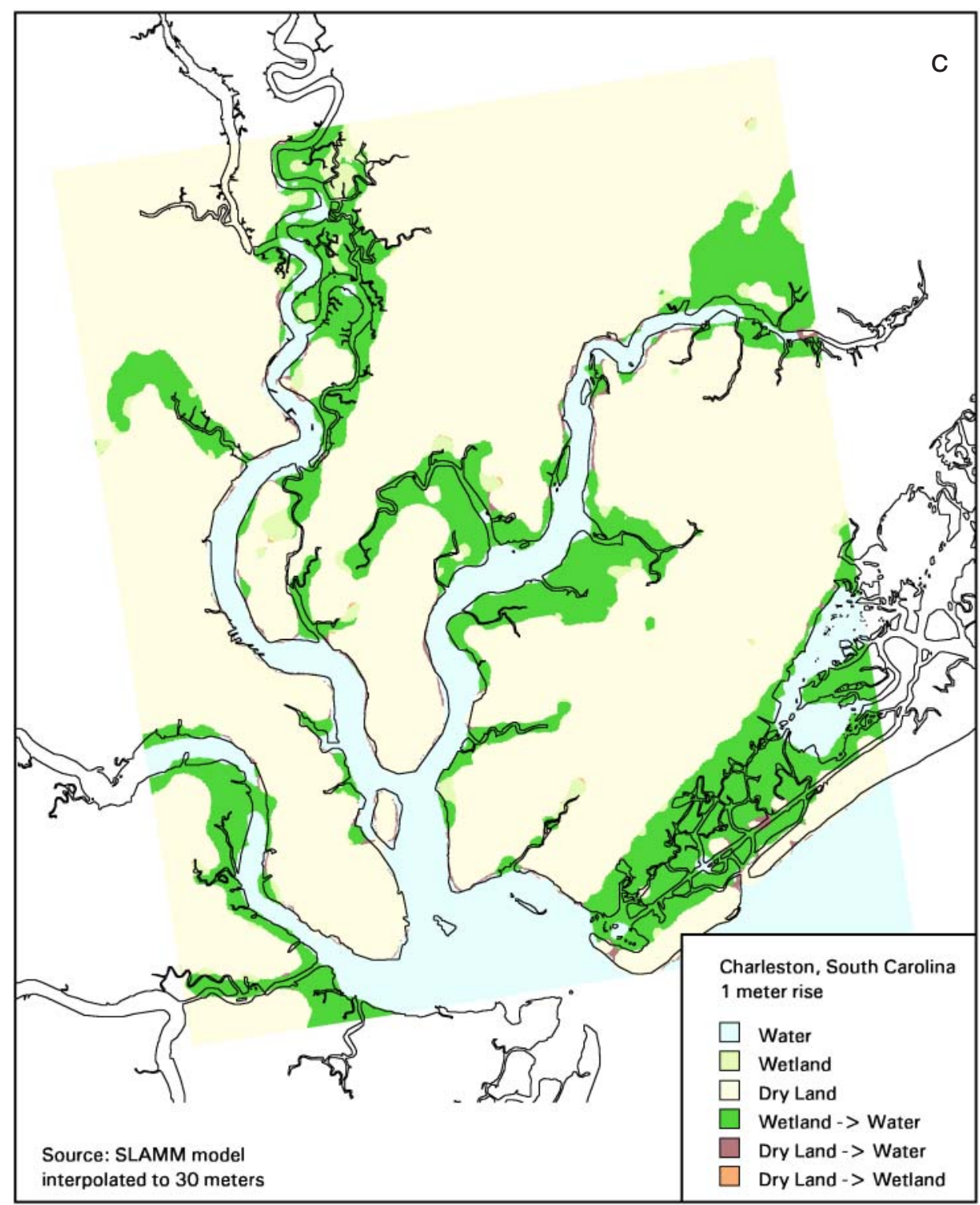

Fig. 7 (continued)

that is currently land, one would expect our tabulations to overstate by $50 \%$ the land below the $1.5 \mathrm{~m}$ contour, even if our maps perfectly depict the location of the $1.5 \mathrm{~m}$ contour. To the extent that this explains the discrepancy, our maps illustrating the 1.5 and $3.5 \mathrm{~m}$ contours can be accurate even though our tabulations overstate the amount of very low land.

The $4000 \mathrm{~km}^{2}$ discrepancy for Florida probably results in part for the same reasons; the LANDSAT data that Park et al. used in the EPA Report to Congress assumed a greater amount of open water in the Everglades than our overlay of the DEM and NOAA shorelines. In addition, the EPA Report to Congress assumed that even with a $2 \mathrm{~m}$ rise in sea level about $2500 \mathrm{~km}^{2}$ of South Florida's coastal wetlands would be able to accrete vertically enough to survive rising sea level. ${ }^{52}$ Hence one would expect that the EPA's estimate of the land likely to be lost would be less than the amount of very low land. Finally, the EPA Report to Congress underestimated the total amount of wetlands along the Gulf Coast by approximately $1500 \mathrm{~km}^{2}$, compared with the area of coastal wetlands estimated by NOAA. ${ }^{53}$

${ }^{52}$ See Titus \& Greene (1989, Table 4$)$
${ }^{53}$ See Titus \& Greene (1989, Table 3 ) 


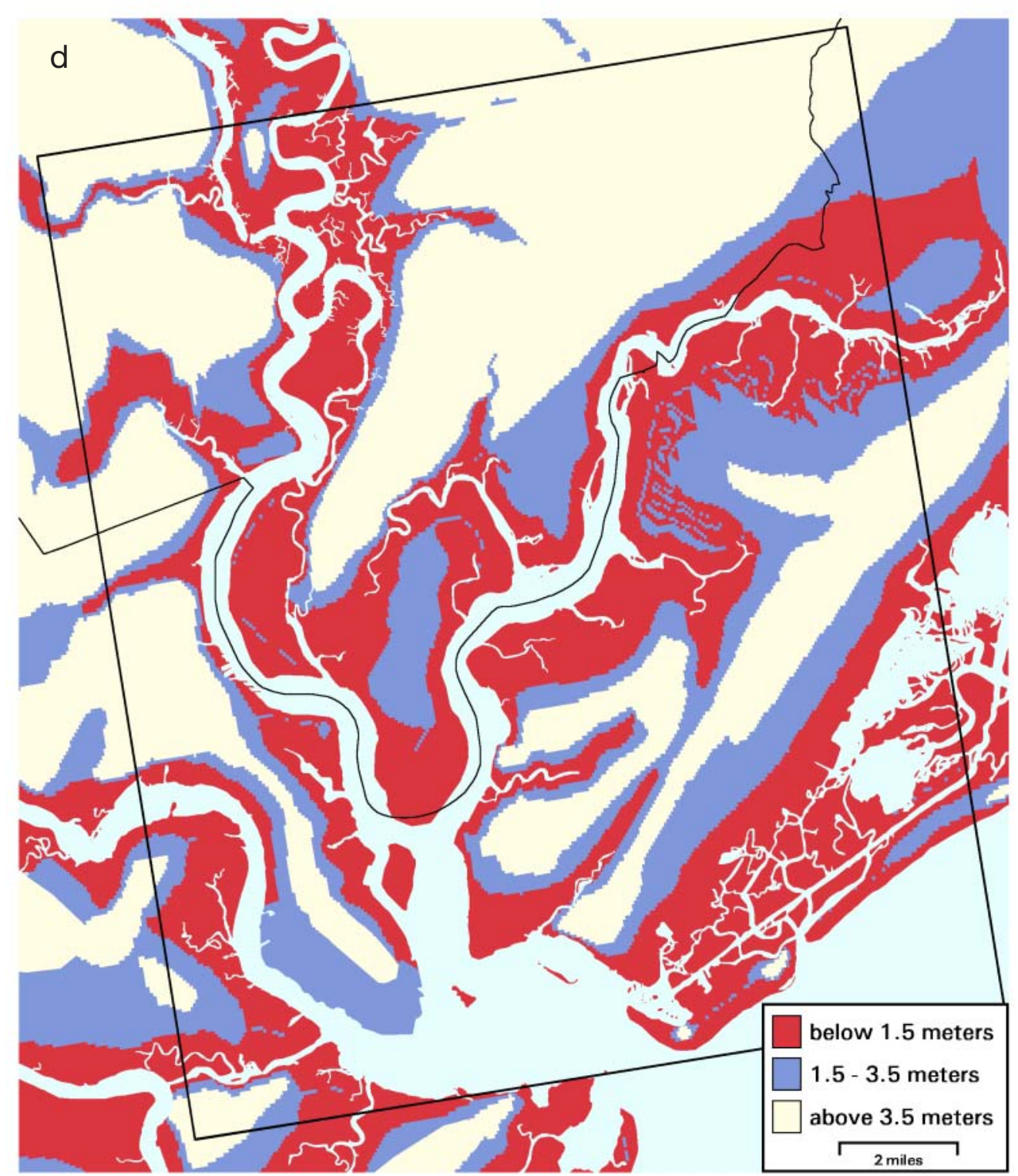

Fig. 7 (continued)

\section{CONTEXT}

\subsection{Interpreting the results}

Given the focus of this paper on elevations, one might logically ask: What is the relevance of the 1.5 and $3.5 \mathrm{~m}$ contours? Today, the $1.5 \mathrm{~m}$ contour is generally $130 \mathrm{~cm}$ above sea level-and thus, in a typical area with a $1 \mathrm{~m}$ spring tidal range, about $80 \mathrm{~cm}$ above spring high water. ${ }^{54}$ Previous EPA studies (Titus \& Narayanan 1995, 1996) estimated that sea level is likely to rise $90 \mathrm{~cm}$ along the US coast by the year 2160 , with a $6 \%$ chance that such a rise will occur by the year 2100 . Thus, at a typical site, the $1.5 \mathrm{~m}$ contour would be flooded by spring high tides (i.e., high tides during new and full moons) when sea level rises $80 \mathrm{~cm}$,

\footnotetext{
${ }^{54}$ The elevation contours on topographic maps are generally measured with respect to the NGVD. Along most of the Atlantic Coast, mean sea level is 10 to $20 \mathrm{~cm}$ above the NGVD zero elevation, for two reasons. First, sea level has risen by 10 to $20 \mathrm{~cm}$ along much of the US coast since 1929. Second, even in 1929, the NGVD was not precisely at mean sea level in most areas. For a comparison of mean sea level with the NGVD elevation, see the NOAA published benchmark sheets, Oceanographic and Products Services Division of the National Ocean Service, at http://www.opsd.nos.noaa.gov/bench.html
} 
Table 4. Area of land close to sea level estimated by this study and EPA Report to Congress. Values are areas $\left(\mathrm{km}^{2}\right)$ of land with elevation less than $1.5 \mathrm{~m}$

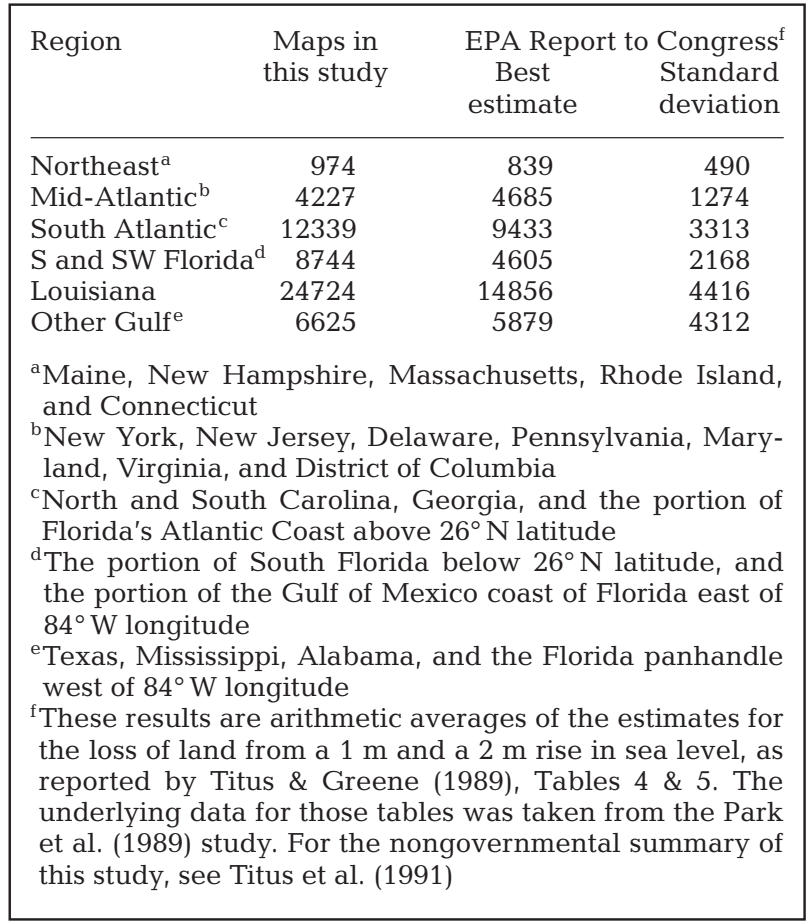

which has a $50 \%$ chance of occurring by the year 2125 and a $5 \%$ chance by the year 2100. IPCC (1996a) estimated that global warming is likely to contribute $45 \mathrm{~cm}$ but could contribute as much as $85 \mathrm{~cm}$ to sea level by the year 2100; when one factors in local subsidence, these IPCC estimates are consistent with the EPA estimates. Thus, as a general rule, it is reasonable to assume that the area below the $1.5 \mathrm{~m}$ contour is at risk of tidal inundation from the projected rise in sea level over the next century, and is likely to be inundated with in the next 2 centuries.

Based on similar reasoning, the $3.5 \mathrm{~m}$ contour would be flooded bi-weekly by the time sea level rises $2.8 \mathrm{~m}$, which has about a $5 \%$ chance of occurring by the year 2200. In a typical coastal area where the $100 \mathrm{yr}$ flood surge is about $2.5 \mathrm{~m}$ above the vertical datum, the $3.5 \mathrm{~m}$ contour also represents the flood plain resulting from a $1 \mathrm{~m}$ rise in relative sea level, which has about a $50 \%$ chance of occurring in the next $200 \mathrm{yr}$. Finally, the $3.5 \mathrm{~m}$ contour might be viewed as the area that would be flooded by daily high tide in the very long run from a doubling of $\mathrm{CO}_{2}$. IPCC (1996a) reports that stabilizing $\mathrm{CO}_{2}$ at $650 \mathrm{ppm}$ could add $150 \mathrm{~cm}$ to sea level in the next $500 \mathrm{yr}$. Current trends alone will raise sea level along the US coast by about $150 \mathrm{~cm}$ in $500 \mathrm{yr}$; hence the total rise would be $3 \mathrm{~m}$, which would put mean high water about $3.6 \mathrm{~m}$ above the vertical datum in the typical coastal area.

\subsection{Substantive implications}

What can people learn from these maps? From the standpoint of the literature, the maps have identified a few areas that previous assessments have failed to highlight. From the standpoint of risk communication, the maps have helped to identify priority areas for communicating the implications of sea level rise.

The most significant contribution of these maps to our understanding of vulnerability to sea level rise is probably our finding that North Carolina has the third largest area of land close to sea level within the United States. The literature has long emphasized (e.g., Barth \& Titus 1984, Louisiana Wetland Protection Panel 1987) the extreme vulnerability of Louisiana, which is also subsiding. Assessments have also focused on the potential vulnerability of the Florida Everglades (e.g., Park et al. 1989). But because previous assessments only sampled the coast, they did not provide any kind of indication of vulnerability at the state level, other than for those two states (Armentano et al. 1988, Park et al. 1989, Titus et al. 1991). Apart from Louisiana and Florida, the literature has instead tended to emphasize the potential vulnerability of all barrier islands and coastal wetlands (e.g., IPCC 1996b). Both our national-scale map (Fig. 3) and Table 3 suggest a third entry in anyone's list of vulnerable states: North Carolina has as much land as The Netherlands within $1 \mathrm{~m}$ of sea level. ${ }^{55}$

Visual inspection of Fig. 3 also suggests that the fourth largest concentration of very low land is along the central portion of the Eastern Shore of Chesapeake Bay. This low area includes Accomac County, Virginia, and the Maryland counties of Somerset, Wicomoco, and Dorchester. This finding is not a total surprise, because Michael Kearney and Court Stevenson of the University of Maryland have demonstrated and publicized the gradual inundation and erosion of both dry and wet lands in Blackwater National Wildlife Refuge in Dorchester County (see, e.g., Kearney \& Stevenson 1985). However, until now, most attention has been limited to the wildlife refuge; it is now clear that the entire bay shores of all 4 counties could retreat by 5 to $10 \mathrm{~km}$ - or more.

Although our original concept was that the maps themselves would be a risk communication tool, we found that they also helped us to target the areas where risk communication might be important. As a result, we made site visits to the low areas in both regions and met with local planning officials. Like Christopher Columbus' 'discovery' of America, our findings need to be viewed more as information trans-

\footnotetext{
${ }^{55}$ Compare Table 3 with IPCC (1996b, p. 173, Table 5-4), which estimates that $2165 \mathrm{~km}^{2}$ of land could be flooded with a $1 \mathrm{~m}$ rise in sea level if no dikes existed
} 
fer than as true discovery, because what we learned would hardly come as a surprise to the inhabitants, who realize how low their communities are. 'I don't need someone from Washington, D.C. telling me that our County is low' the assistant planner of Dare County, North Carolina, told us in one interview.

Throughout the low areas along Chesapeake Bay, one can observe that the water in the ditches along most roads rises and falls with the tides. In many areas, including Hooper, Smith, and Tangier Islands, as well as mainland areas near Crisfield, Maryland, and Saxis, Virginia, the marsh is starting to take over people's yards. In most cases, residents continue to mow their lawns, and unless one looks closely one would not even realize that they are mowing salt-tolerant forms of vegetation. According to local officials, ${ }^{56}$ high water levels have led to septic tank failures in some low areas. Although people can continue to inhabit a house in such an area by having the septic tank pumped, it is virtually impossible to sell such a house, given the fact that a working septic system is required to obtain a mortgage. As a result, one often finds abandoned homes standing in the marsh, sometimes next to inhabited homes of a similar vintage standing on adjacent higher ground. This natural shoreline movement would never be tolerated along much of the well-developed ocean coast. ${ }^{57}$ But in response to our suggestion that perhaps property owners in Somerset County could bring in fill to elevate their lots as the sea rises, the assistant planner shook his head and stated 'When it's time to go, it's time to go'. ${ }^{58}$

The landward migration of coastal wetlands is not, however, causing people to abandon homes everywhere along the Eastern Shore. The town of Crisfield has an old dike, underground street drains, and a sewage treatment plant. Recently, the sewer system was extended to serve homes in some of the adjacent communities. Although this extension presumably helps near-term water quality, it also will probably cause a net loss of wetlands. Instead of abandoning homes as their septic systems fail, people can simply hook into the sewer; and with the additional infrastructure in place, it is more likely that the flood levee will eventually be extended to protect these areas as well. Ironically, a public works project to protect water quality may ultimately harm the environment.

\footnotetext{
${ }^{56}$ Interview with Sandy Manter, planner of Accomac County, July 1998; interview with Joan Kean, Somerset County Planner, August 1998

${ }^{57}$ See, e.g., Bates (1999), who quotes James Mancini, the mayor of Long Beach Island, New Jersey: 'There is no question where we have development, it must be maintained. Retreat is ridiculous. Anybody who puts any merit in it is absolutely ridiculous'

${ }^{58}$ Interview with Somerset County planning staff, August 1998
}

The vulnerable part of North Carolina can be divided into 3 areas. The Outer Banks is vulnerable to erosion, rather than the inundation of low land, and is hence outside the scope of our analysis. Interested readers may wish to consider analyses by Orrin Pilkey and his colleagues (e.g., Pilkey et al. 1998) as well as a National Park Service (1999) report on the recent landward relocation of the Cape Hatteras Lighthouse. Just south of the Outer Banks is the low-lying peninsula that includes the town of Sea Level, North Carolina, which fortunately is mostly about $1 \mathrm{~m}$ above sea level. The communities along this peninsula are similar to the low areas along Chesapeake Bay, although the tidal ditches tend to be somewhat wider to accompany the more intense rainfall that North Carolina occasionally receives from hurricanes.

The largest low area, however, is the Pamlico-Albemarle Peninsula which separates Pamlico and Albemarle Sounds. Because the only outlets to the sea for this large estuary are a few narrow inlets, these sounds have almost no tides. As a result, the ditches do not rise and fall with the tides. The dry land just above the marsh tends to drain very slowly, and in many cases the fill for elevating the roads above the wetland elevation was provided by excavating a ditch; hence the ditches tend to be more than $3 \mathrm{~m}$ wide. Many small communities are below the $1.5 \mathrm{~m}$ contour.

Having identified these vulnerable areas, we are now working with local officials to identify those areas that are likely to be protected from the rising sea and those that will be abandoned. The legal, economic, and institutional need for such assessments were documented by a study in the 'Maryland Law Review' (Titus 1998); but our priorities for selecting areas for cooperation were largely motivated by the maps developed in this study.

What have we learned about the vulnerability of other areas? Overall, our main step forward is that, instead of regional results based on discrete case studies, we have a continuous image of where the low land can be found along the Atlantic and Gulf coasts. Table 2 suggests that Texas is probably the state with the fourth greatest amount of low land; because this low land is next to Louisiana and also spread over a $600 \mathrm{~km}$ coast, it is less noticeable on a national-scale map than the low land along Chesapeake Bay, most of which is along a $60 \mathrm{~km}$ stretch of shore. Fortunately, the topographic maps suggest that the very low areas in Texas are almost all marsh rather than inhabitable dry lands, unlike the areas along Chesapeake Bay and North Carolina, where the marsh is accompanied by many low-lying towns. The relative lack of development may have resulted because the Texas coast is more likely to experience storm surges from hurricanes than Chesapeake Bay and the Pamlico and Albemarle Sounds. 
Moreover, as with Louisiana, eastern Texas has lost land as a result of subsidence (see, e.g., Jensen 1985, Leake 1997) and coastal erosion (Morton \& Paine 1990); hence public awareness of the effects of relative sea level rise and erosion is relatively high.

Because our maps give a continuous indication of vulnerability to sea level rise, we hope that they will be useful for people interested in making direct observations of the vulnerable areas. Nevertheless, we do not recommend that people cite the results of Table 3 as substantive estimates of the land close to sea level in specific states, for 2 reasons. First, the results probably have an error of at least a factor of 2, except for North Carolina, Louisiana, and Florida. (Missing the $1.5 \mathrm{~m}$ contour by, for example, $1 \mathrm{~km}$, has a much smaller percent error in cases where that contour is $50 \mathrm{~km}$ inland than in areas where it is only $1 \mathrm{~km}$ inland.) Second, it would be feasible to develop a more realistic estimate of the land vulnerable to sea level rise by using our results to extrapolate the more careful sample-site analysis conducted in the 1989 EPA Report to Congress. Although such an analysis is outside the scope of what we can do here, the likelihood of such a study being undertaken is great enough that the reader tempted to cite Table 3 may be better advised to consult subsequent analyses for better estimates.

\subsection{Risk communication and caveats}

We hope that these maps prove to be useful for researchers attempting to determine and communicate the implications of accelerated sea level rise along the coastal zone of the United States. For the same reasons that we discourage people from putting too much faith in our tabular state-by-state results, we hope that people will not put too much faith in our maps.

Recognizing that the typical report would not have sufficient space to discuss the methods, we suggest that one of the following caveats be incorporated either in figure captions or accompanying text of any paper that reproduces these maps.

Research papers. 'This map is based on modeled elevations, not actual surveys or the precise data necessary to estimate elevations at specific locations. The map is a fair graphical representation of the total amount of land below the 1.5 and 3.5 meter contours; but the elevations indicated at particular locations may be wrong. Those interested in the elevations of specific locations should consult a topographic map. Although the map illustrates elevations, it does not necessarily show the location of future shorelines. Coastal protection efforts may prevent some lowlying areas from being flooded as sea level rises; and shoreline erosion and the accretion of sediment may cause the actual shoreline to differ from what one would expect based solely on the inundation of low land. This map illustrates the land within 1.5 and 3.5 meters of the National Geodetic Vertical Datum of 1929, a benchmark that was roughly mean sea level in the year 1929 but approximately $20 \mathrm{~cm}$ [or fill in local estimate] below today's sea level.'

Publications for the general public. If possible, the aforementioned caveat should be printed; but sometimes space constraints will make that impossible. We recommend that as much of the following be included as possible: 'Elevations based on computer models, not actual surveys. Coastal protection efforts may prevent some low-lying areas from being flooded as sea level rises. The 1.5 meter contour depicted is currently about 1.3 meters [use local estimate if possible] above mean sea level, and is typically $90 \mathrm{~cm}$ [use local estimate if possible] above mean high tide. Parts of the area depicted in red will be above mean sea level for at least 100 years and probably 200 years [use local estimates if possible]. The 3.5 meter contour illustrates the area that might be flooded over a period of several centuries.'

Newspapers and magazines. The amount of space available for a caption is typically even less in a newspaper or wide-circulation magazine. We must simply recognize that those publications are unlikely to explain the difference between elevation and land lost due to sea level rise, let alone the potential errors. Fortunately, however, magazines and newspapers tend to publish such small maps that the scale will probably be an order of magnitude smaller than what we offer here, which substantially reduces the need for a caveat. The January 1, 2000, edition of The 'New York Times' published a few of our maps after this article was accepted for publication. We found their caveat to be acceptable. With minor edits, that caveat read: 'Regions shown in black are some of the areas that could be flooded at high tide if global warming causes sea level to rise $2 \mathrm{ft}$ in the next 100 years. The indicated areas account not only for the effects of global warming, but also for other effects such as tidal variations and land subsidence.'

\section{LITERATURE CITED}

Armentano TV, Park RA, Cloonan CL (1988) Impacts on coastal wetlands throughout the United States. In: Titus JG (ed) Greenhouse effect, sea level rise, and coastal wetlands. US Environmental Protection Agency, Washington, DC, p 87-149; available at: http://www.epa.gov/ globalwarming/publications/impacts/sealevel/index.html

Asthana V, Surendra S, Venkatesan S (1992) Assessment of the vulnerability of Orissa and West Bengal, India, to sea level rise. In: Coastal zone management subgroup, Intergovernmental Panel on Climate Change, Global climate change and the rising challenge of the sea. Environmental 
Protection Agency and National Ocean Service, Washington, DC

Awosika LA, French GT, Nichols RJ, Ibe CE (1992) The impacts of sea level rise on the coastline of Nigeria. In: Coastal zone management subgroup, Intergovernmental Panel on Climate Change. Global Climate Change and the Rising Challenge of the Sea. Environmental Protection Agency and National Ocean Service, Washington, DC

Barth MC, Titus JG (eds) (1984) Greenhouse effect and sea level rise: a challenge for this generation. Van Nostrand Reinhold, New York

Bates TB (1999) Sink or swim. Asbury Park Press, Neptune, NJ, Millenium Section (July 4, 1999); also available at http://www.injersey.com/2000/story/1,2297,195727,00.html

Bruun P (1962) Sea level rise as a cause of shore erosion. J Waterways Harbors Div (ASCE) 88:116-130

Camber G (1992) Global climate change and the rising challenge of the sea. Assessment of the vulnerability of coastal areas in coastal zone management subgroup, Intergovernmental Panel on Climate Change

Crawford M, Holthius P, Makroro C, Nakaasaki E, Sullivan S (1992) Assessment of the vulnerability of Majuro Atoll to sea level rise. In: Global climate change and the rising challenge of the sea. Coastal Zone Management Subgroup, Intergovernmental Panel on Climate Change. Environmental Protection Agency and National Ocean Service, Washington, DC

Dunbar JB, Britsch LD, Kemp EB (1992) Land loss rates: Report 3, Louisiana coastal plain. US Army Corps of Engineers, New Orleans, LA

Eastman JR, Gold S (1996) Spatial information systems and assessment of the impacts of sea level rise. In: Lorup E, Strobol J (eds) IDRISI GIS 96 ' Salzburger Geographische Materialien, Heft 25. Selbstverlag des Instituts für Geographie der Universität Salzburg; available at http://www. sbg.ac.at/geo/idrisi/idrgis96/eastman1/slrise.htm

El-Raey M, Nasr S, Frihy O, Desouki S, Dewidar K (1995) Potential impacts of accelerated sea-level rise on Alexandria Governorate, Egypt. J Coast Res Spec Iss 14:190-204

Environmental Protection Agency (1983) Projecting future sea level rise. Strategic Studies Staff, US Environmental Protection Agency, Washington, DC

Environmental Protection Agency (1989) The potential impacts of global climate change on the United States. United States Environmental Protection Agency, Washington, DC

Federal Emergency Management Agency's, Federal Insurance Administration (1991) Projected impact of relative sea level rise on the National Flood Insurance Program. Federal Emergency Management Agency, Washington, DC

Han M, Hou J, Wu L (1995) Potential impacts of sea level rise on China's coastal environment and cities: a national assessment. J Coast Res Spec Iss 14:79-95

Huq A, Ali SI, Rahman AA (1995) Sea level rise and Bangladesh: a preliminary analysis. J Coast Res Spec Iss 14:44-53

Intergovernmental Panel on Climate Change (1990) The IPCC scientific assessment. Cambridge University Press, Cambridge

Intergovernmental Panel on Climate Change (1996a) Climate change 1995: the science of climate change. Cambridge University Press, Cambridge

Intergovernmental Panel on Climate Change (1996b) Climate change 1995: impacts, adaptations, and mitigation of climate change. Cambridge University Press, Cambridge

Intergovernmental Panel on Climate Change (1998) The regional effects of climate change. Cambridge University Press, Cambridge
Jensen R (1985) Stopping the sinking. Texas Water Resource 11(3); available at http://twri.tamu.edu/twripubs/WtrResrc/v11n3/text-0.html

Jogoo V (1992) Assessment of the vulnerability of Mauritius to sea level rise. In: Global climate change and the rising challenge of the sea. Coastal Zone Management Subgroup, Intergovernmental Panel on Climate Change

Kana TW, Michel J, Hayes MO, Jensen JR (1984) The physical impact of sea level rise in the area of Charleston, South Carolina. In: Barth MC, Titus JG (eds) Greenhouse effect and sea level rise: a challenge for this generation. Van Nostrand Reinhold, New York, p105-150; available at: http://www.epa.gov/globalwarming/publications/impacts/ sealevel/index.html

Kana TW, Baca BJ, Williams ML (1986) Potential impacts of sea level rise on wetlands around Charleston, South Carolina. US Environmental Protection Agency, Washington, DC

Kana TW, Baca BJ, Williams ML (1988) Charleston case study. In: Titus JG (ed) Greenhouse effect, sea level rise, and coastal wetlands. EPA-230-05-86-013, US Environmental Protection Agency, Washington, DC; available at http://www.epa.gov/globalwarming/publications/impacts/ sealevel/wetlands.html

Kay R, Eliot I, Klem G (1992) Assessment of the vulnerability of Geographe Bay, Australia, to sea level rise. In: Global climate change and the rising challenge of the sea. Coastal Zone Management Subgroup, Intergovernmental Panel on Climate Change. Environmental Protection Agency and National Ocean Service, Washington, DC

Kearney MS, Stevenson JC (1985) Sea level rise and marsh vertical accretion rates in Chesapeake Bay. In: Magoon OT et al. (eds) Coastal zone '85. American Society of Civil Engineers, New York

Keeling CD, Bacastow RB, Carter AF, Piper SC, Whorf TP, Heinmann M, Mook WG, Roeloffzen H (1989) A three dimensional model of atmospheric transport based on observed winds: analysis of observational data. In: Peterson DH (ed) Aspects of climate variability in the Pacific and Western Americas. Geophys Monogr 55:165-236

Keeling CD, Whorf TP, Wahlen M, van der Plicht J (1995) Interannual extremes in the rate of atmospheric carbon dioxide since 1980. Nature 375:666-670

Landsea CW (1999) FAQ: hurricanes, typhoons, and tropical cyclones. Part G: Tropical cyclone climatology. Miami: National Hurricane Center; available at http://www.aoml. noaa.gov/hrd/tcfaq/tcfaqG.html\#G9

Leake SA (1997) Land subsidence from ground-water pumping. Reston: US Geological Survey; available at http://geochange.er.usgs.gov/sw/changes/anthropogenic/subside/

Leatherman SP (1984) Coastal geomorphic responses to sea level rise in and around Galveston, Texas. In: Barth MC, Titus JG (eds) Greenhouse effect and sea level rise: a challenge for this generation. Van Nostrand Reinhold, New York, p 151-178; available at http://www.epa.gov/ globalwarming/publications/impacts/sealevel/wetlands.html

Leatherman SP, Nichols RJ, Dennis KC (1995) Aerial videotape-assisted analysis: a cost-effective approach to assess sea level rise impacts. J Coast Res Spec Issue 14:15-25

Louisiana Wetland Protection Panel (1987) Saving Louisiana's wetlands: the need for a long-term plan of action. US Environmental Protection Agency, Washington, DC

Lyle SD, Hickman LH, Debaugh HA (1986) Sea level variations in the United States. Rockville, MD (USA): National Oceanographic and Atmospheric Administration

Mercer JH (1978) West Antarctic ice sheet and $\mathrm{CO}_{2}$ greenhouse effect: a threat of disaster? Nature 271:321-325 
Mimura N, Isobe M, Hosakawa Y (1992) Impacts of sea level rise on Japanese coastal zones and response strategies. In: Intergovernmental Panel on Climate Change, 1996. Climate change 1995: the science of climate change. Cambridge University Press, Cambridge

Morton R, Paine T (1990) Coastal land loss in Texas, an overview. Gulf Coast Assess Geol Soc Trans XL:625-634

National Academy of Sciences (1983) Changing climate. National Academy Press, Washington, DC

National Academy of Sciences (1985) Glaciers, ice sheets, and sea level. Polar Research Board, Committee on Glaciology, Mark Meier, Chairman. National Academy Press, Washington, DC

National Environmental Trust (1998) The Massachusetts coast: on the front lines of global warming. National Environmental Trust, Washington, DC (accessed: April 1, 1999); available at http://www.envirotrust.com/PDF/Mass Coast.pdf

National Geodetic Survey (1998) National height modernization study. Written by Dewberry and Davis, and Psomas and Associates. National Geodetic Survey, Silver Spring, MD; available at http://www.acsm.net/heightrpt.html

National Oceanic and Atmospheric Administration (1999) NOAA's medium resolution digital vector shoreline. Office of Ocean Resources Conservation and Assessment, Silver Spring, MD

National Oceanic and Atmospheric Administration (2000) NOAA's medium resolution digital vector shore line. National Geophysical Data Center, Boulder, CO (accessed: April 1, 2000); available at http://www.ngdc.noaa.gov/ mgg/shorelines/noaamrdvs.html

National Park Service (1999) Cape Hatteras lighthouse relocation articles and images. National Park Service, Washington, DC; available at http://www.nps.gov/caha/lrp.htm

Niang I, Dennis KC, Nichols RJ (1992) The impacts of sea level rise on the coastline of Senegal. In: Global climate change and the rising challenge of the sea. Coastal Zone Management Subgroup, Intergovernmental Panel on Climate Change. Environmental Protection Agency and National Ocean Service, Washington, DC

Nicholls RJ, Leatherman SP, Dennis KC, Volonte CR (1995) Impacts and responses to sea level rise: qualitative and quantitative assessments. J Coast Res Spec Issue 14:26-41

Office of Science and Technology Policy (1997) Climate change state of knowledge. Office of Science and Technology Policy, Washington, DC (accessed: April 1, 2000); available at http://clinton4.nara.gov/Initiatives/Climate/ content.html

Park RA, Treehan MS, Mausel PW, Howe RC (1989) The effects of sea level rise on US coastal wetlands. In: Potential effects of global climate change on the United States. Environmental Protection Agency, Washington, DC

Permanent Service for Mean Sea Level (1999) Table of MSL secular trends derived from PSMSL RLR data. PSMSL, Proudman Oceanographic Laboratory, Bidston Observatory, UK Natural Environment Research Council, Birkenhead (accessed: April 1, 2000); available at http://www.nbi. ac.uk/psmsl/datainfo/rlr.trends

Pilkey OH, Neal WJ, Riggs S, Pilkey D, Webb CA (1998) The

Editorial responsibility: Lawrence Kalkstein,

Newark, Delaware, USA
North Carolina shore and its barrier islands: restless ribbons of sand (living with the shore). Duke University Press, Durham, NC

Sallenger A and 8 others (1999) Airborne laser study quantifies El Niño-induced coastal change. EOS Trans 80(8): 89-93

Schnack EJ, Dennis KC, Nichols RJ, Mouzo F (1992) Impacts of sea level rise on the coast of Argentina. In: Global climate change and the rising challenge of the sea. Coastal Zone Management Subgroup, Intergovernmental Panel on Climate Change

Schneider SH, Chen RS (1980) Carbon dioxide flooding: physical factors and climatic impact. Annu Rev Energy 5:107-140

Titus JG (1998) Rising seas, coastal erosion, and the takings clause: how to save wetlands and beaches without hurting property owners. Maryland Law Rev 57:1279-1399; available at http://www.epa.gov/globalwarming/publications/ impacts/sealevel/takings.html

Titus JG, Greene M (1989) An overview of the nationwide impacts of sea level rise. In: Potential impacts of global climate change on the United States. US Environmental Protection Agency, Washington, DC

Titus JG, Narayanan V (1995) The probability of sea level rise. EPA 230-R95-008, Environmental Protection Agency, Washington, DC; available at http://www.epa.gov/global warming/publications/impacts/sealevel/probability.html

Titus JG, Narayanan V (1996) The risk of sea level rise: a Delphic Monte Carlo analysis in which twenty researchers specify subjective probability distributions for model coefficients within their respective areas of expertise. Clim Change 33:151-212; available at http://www.epa.gov/ globalwarming/publications/impacts/sealevel/risk_of_rise. html

Titus JG, Park RA, Leatherman S, Weggel R, Greene MS, Mansel PW, Brown S, Gaunt C, Treehan M, Yohe G (1991) Greenhouse effect and sea level rise: the cost of holding back the sea. Coastal Management. 19(3):171-204; available at http://www.epa.gov/globalwarming/publications/ impacts/sealevel/cost_of_holding.html

US Dept of Commerce (1987) District of Columbia 8594900. Tidal bench marks. US Dept of Commerce, NOAA, National Ocean Service; available at http://co-ops.nos. noaa.gov/benchmarks/8594900.html

United States Geological Survey (1999) USGS digital elevation model data. United States Geological Survey, Reston, VA (accessed: January 1, 1999); available at http:// edcwww.cr.usgs.gov/Webglis/glis/hyper/guide/usgs_dem. See also http://rockyweb.cr.usgs.gov/elevation/dpi_dem. html\#document

Volonte CR, Nichols RJ (1995) Sea level rise and Uruguay: potential impacts and responses. J Coast Res Spec Issue 14:285-302

Yohe G (1990) The cost of not holding back the sea. Coastal Manage 18:403-432

Yohe G, Neumann J, Marshall P, Ameden H (1996) The economic cost of greenhouse-induced sea-level rise for developed property in the United States. Clim Change 32: $387-410$

Submitted: April 22, 1999; Accepted: June 6, 2000

Proofs received from author(s): September 11, 2001 